\title{
The Metrics of Seto Choral Laments in the Context of Runosong Metrics
}

\author{
Janika Oras, Žanna Pärtlas, Mari Sarv, Andreas Kalkun*
}

\begin{abstract}
The aim of this paper is to get an overview of the lament metrics in Seto oral song tradition, which belongs to the southern border area of the Finnic song tradition, and the placement and historical development of lament metrics in the framework of the whole Seto oral song tradition. In the paper the metrical structures of two main genres of Seto choral laments - choral bridal laments and death laments - are analysed that share common features with solo laments and are similar to the structures of Seto runosongs. Metrical structures of the laments are detected based on sound recordings, taking into account the linguistic structure of the lines and the varied realization of it in a musical performance rhythm.

The analysis showed that laments' metrics where 5-unit end structures play an important role, differs the most from the main body of runosongs and is structurally more similar to a group of runosongs with refrains and varying line length. Outlining the development patterns of the metrical system of Seto songs, the influences of local unique musical tradition with varied rhythmic structures atypical of the most runosong area, specific functions of ritual song genres, historical changes in language, as well as possible external connections to early eastern and southern song cultures are highlighted.
\end{abstract}

Keywords: Seto runosong and laments, Finnic runosong and lament tradition, choral and solo laments, musical performance

Runosong, the ancient Finnic singing tradition, is estimated to have emerged approximately two millennia ago and, over the course of history, unique regional metric traditions have evolved within this tradition (Sarv 2015, 2019, Kallio et al. 2017, Frog 2019). The differences between these regional metric traditions stem from both changes in the local language and/or poetic and musical system - either as a result of internal evolution or the influence of other cultures. One of the most complex metric systems has developed on the southern border of the Finnic runosong tradition - in the Seto region, or Setomaa.

* Authors' addresses: Janika Oras, Vanemuise 42, Tartu, 51003, Estonia; e-mail: janika.oras@ folklore.ee; Žanna Pärtlas, Tatari 13, 10116 Tallinn, Estonia; e-mail: zhanna.partlas@eamt.ee; Mari Sarv, Vanemuise 42, Tartu, 51003, Estonia; e-mail: mari.sarv@folklore.ee; Andreas Kalkun, Vanemuise 42, Tartu, 51003, Estonia; e-mail: andreas.kalkun@folklore.ee. 
Compared to runosongs in general, a characteristic feature of Seto runosong meter is the use of different versions of meter in different runosong groups. In our previous studies we described two versions of meter of runosongs. One of these versions, in which the lines are of stable length throughout the song, is a main meter in the Seto tradition. It has been analyzed in songs sung with the so-called 'feast melody' (praasnigaviis in Seto language) (Oras, Iva 2017). The second version of meter is associated with a share of songs with a refrain, in which the length of the line varies throughout the song - namely, harvest song (Seto lelotamine), wedding song (kaaskôlómine) and 'The Horse Game' (Oras 2019; Oras, Sarv 2021).

This article analyzes the meter of Seto laments. Seto laments share close similarities with Seto runosongs, still they are not considered as a subcategory of runosongs. Laments are not 'songs' from the emic point of view, since they have a specific ritual function, manner of singing and improvised text. In terms of music and performance, the Seto solo laments (death laments, also those performed to send recruits off to war) are quite far from Seto runosongs. At the same time, Seto choral laments (bridal laments, some recruit and death laments) resemble them closely. Like runosongs, choral laments are performed by a lead singer and the choir, who generally repeats the song line and the tune sung by the lead singer; there is also no difference between the musical style of choral laments and choral songs of the older layer. ${ }^{1}$

In terms of meter, Seto laments are slightly different from runosongs, thus they can be considered as a version of runosong meter or as a distinct meter close to runosong meter. Herewith the metric structure of solo laments coincides with the metrics of choral laments, although solo laments are metrically slightly more varied, characteristic to a solo genre.

Variative length of lines is a common feature of a share of refrain songs and laments. A melody type used in singing harvest songs with a refrain is most similar to laments in terms of musical rhythmic structure (Pärtlas 2018: 222, Oras 2019). ${ }^{2}$ Still, the verse structures of refrain songs and laments

\footnotetext{
1 Audio examples of Seto choral laments are available at: https://www.folklore.ee/pubte/eraamat/rahvamuusika/en/052-Morsja-itkeb-vennale; https://www.folklore.ee/pubte/eraamat/rahvamuusika/en/054-Neiud-itkevad-sopra. For an example of a solo death lament, see: https://www.folklore.ee/pubte/eraamat/rahvamuusika/en/053-Tutar-itkeb-ema.
}

2 This tune is also available in shorter variants, which, however, show no direct resemblance to laments. The overlap of the structures of the lament and the harvest song may not be accidental. For example, in Greece, a certain kind of singing in the field during the harvest has been interpreted as mourning for the deity of fertility who, according to a widespread myth, died during the harvest (Olivetti 2007, see also Frazer 1996: 857-866). 
have obvious differences. To understand the structural differences in the versification of Seto runosongs and laments we have compared the analysis results of lament lines with the analysis results of the line structures of the two runosong groups - the songs with a stable line length and refrain songs. One of our aims is to explain the reciprocal relationship of laments and runosongs and the possible ways these genres developed.

When juxtaposing different song groups and outlining the possible development patterns of the singing tradition, it is important to take into account the unique musical features of the Seto songs, compared to the Finnic runosong in general. One of the rare features of the musical style of Seto runosongs and choral laments is an archaic polyphony, which differs from the mainly one-part singing culture of the Finnic tradition, but also a very unusual scale system (pitch, intervals), which is unlike any other known in Estonia or among the neighboring peoples. ${ }^{3}$ Another characteristic feature of Seto singing is the relationship between verse and melody structures. While in the Finnic runosong tradition, an eight-note melody usually corresponds to an octosyllabic line, suggesting an initial symbiosis and the common origin of the melody and verse, Seto melodies are often considerably longer than eight notes. Since Seto singing is also syllabic by nature, various additional words, refrain words and repetitions have been added to align the long melodies with the octosyllabic line of runosong verse. ${ }^{4}$ At the same time, the octosyllabic main line remains recognizable in Seto songs and the use of additional elements depends on the structure of a specific tune.

The structural complexity of the songs prompts the question whether Seto tunes used to be originally shorter, and the melody and verse line extended simultaneously throughout the history or were the octosyllabic runosong lines in the Seto region matched to longer melodies originating in some other musical tradition (Rüütel 1990: 106; Pärtlas 2006b: 27-28). An altogether different question is whether the musical and poetic form of Seto laments is derived only

\footnotetext{
3 See below "The musical structure of Seto laments", also Tampere 1934; Kolk 1979; J. Sarv 1980; V. Sarv 1980; Rüütel 1990; Pärtlas 1997, 2001, 2006a, 2006b, 2010a, 2010b; Ambrazevicius, Pärtlas 2011.

4 Since the texts and melodies are not strictly linked in Seto singing, the same text is often adapted to different tune types, using the specific methods of extending the main verse line for every tune type. Thus, the octosyllabic main line of Toomalaul, "Toomas torrõ poisikõnõ" ('Toomas, a nice young man'), can be sung to different melodies using the following variants (the extending elements are marked in italics): "Toomas õks torrõ jal poisikõnõ", "Toomas jo, Toomas torrõ poisikõnõ", “Toomas, Toomas torrõ poisikõnõ, poisikõnõ”, “Toomas torrõ, Toomas jo torrõ poisikõnõ" (the examples are from both the lead singer's and the choir's part).
} 
from runosongs or could their idiosyncratic features have developed somewhat independently from runosongs, on the basis of some other tradition.

The juxtaposition of bridal and death laments, also the comparison of these with two other groups of songs with a different version of meter, helps to cast light on the most general methodological questions prompted by an analysis of verse metrics in musical performance - which is the only way it can be done in oral tradition. Can the meter in texts with highly similar linguistic structures be considered as different if the texts are differently structured and rhythmically organized in the performance? If and how to differentiate between poetic meter as the generalized (deep) structural level, on the one hand, and the varying performance level (in performances using different musical structures), on the other?

The paper opens with an overview of the Seto lamenting tradition and its place within the Finnic lamenting tradition. We will introduce the analyzed material and methods. This is followed by an introduction of previous research on the musical features and metrics of Seto laments and the metrics of Seto runosongs. The analysis of laments provides an overview of their rhythm structure in musical performance, syllable structure and the positioning of words in different degrees of quantity ${ }^{5}$ in the sung lines. Then the characteristics of the metrics of the laments and the two previously analyzed runosong groups are compared against each other, briefly outlining the possible development patterns of these song groups.

\section{Material and methods}

The sources analyzed in this paper are 14 bridal laments (435 lines) and 17 choral death laments (301 lines) - altogether 736 lines (analyse files of the study are available at Oras et al. 2021). Since no other recordings of choral death laments are known, the material is rather scant. Among the choral death laments are two improvisational variants of 'The War Song' by Anne Vabarna, the rhythmic structure of which corresponds to those of laments and they are sung to the same tune than her choral death lament (see footnote 1). The total number of lines does not include the 18 unclear lines that have been excluded

\footnotetext{
5 In the Finnic runosong meter, in general, the quantity distinction of long and short word-initial syllables is relevant. In most of the Estonian language (including South-Estonian and Seto), as a result of language change, the long syllabic quantity divided into long (Q2) and overlong $(\mathrm{Q} 3)$ during the period of considerable changes in the prosodic system in approximately 13th to 16th century (Rätsep 1989: 1518).
} 
from the analysis. The material comes from the collections of audio-recordings of the Estonian Folklore Archives at the Estonian Literary Museum.

Determining the metric structure of the text of a traditional song is a challenging task since the so-called natural verse systems may not employ simple patterns but have evolved alongside the development of language and in reciprocal interaction with the musical tradition used in singing (Lotman 1998: 1847-1848; Ross, Lehiste 2001: 3). The text of a song cannot (always) be studied independently of its performance since the song's melody and performance practices inevitably structure the composition of the verse line (cf. Küper 1988: 274-281; Sarv 2011a: 334). The musical performance of lines using the same tune (or following the same principles of musical/melodic structure) also reveals the metrically equivalent units in different lines. Thus, also in Seto songs, the metric organization of lines is revealed in their performance - dividing the syllables of a line into musical metrical units can theoretically be done in multiple ways. How these ways have been actually realized in the tradition will become known only in the analysis of audio-recordings.

In the paper, we will propose our interpretation of the metrics of Seto laments and juxtapose it with the results of analyzing Seto runosong, attempting to understand the Seto traditional metrical system as a whole. For that purpose, we will compare (a) the linguistic structure of the lines (the syllabic composition, and use of quantity degrees, without taking the performance into account); and (b) the realization of this structure in a musical performance. In the analysis, we have adopted the terms 'performance rhythm group' and 'performance rhythm structure' to refer to the units of musical rhythm and their organization in which textsetting occurs during musical performance.

Syllable structures have been indicated as sequences of numbers, without separating signs (e.g. sul-lõ kal-lu kaa-la ümb-rel-le - 2223). The syllable structures correspond to syllable divisions in ordinary speech (without taking into account the so-called song syllables, in case a syllable is stretched over two musical metrical units in singing - e.g., even though the word va-(a)ht-rõ-hõ is sung over four metric units, it is linguistically a trisyllabic word). Word-final negation particle is regarded as a separate monosyllabic word in case it lasts for the duration of an independent metric unit (saa_as < saa and $\tilde{o s}$, 'can' and 'not', the vowel of the negation word is assimilated with the previous vowel). If the word-final negation particle forms a part of the musical metrical unit together with the final syllable of a verb, it is regarded as a part of the same syllable (o-lõ $i<$ olo and $\tilde{o} i$, 'is' and 'not').

The analysis of quantity degrees differentiates between three degrees of quantity. In addition, it considers as separate groups (a) the long archaic forms in which the apocope or syncope has not taken place and for which it is not 
clear whether the performers perceive these as Q2 or Q3 words (Oras, Iva 2017: 180-181), and (b) of a small group of words that could be used in language as Q2 or Q3 words. The quantity of the words was identified with the help of the Seto language dictionary, sometimes also the dictionary of the Vorru dialect was used (Jüvä 2002; Käsi 2016). Andreas Kalkun, a native speaker of Seto language, identified the quantity of single specific words used only in lamenting based on his intuition.

The performance rhythm structure of a song line consists of the performance rhythm groups of 2 and 3 musical metrical units, which start with a stressed (or secondary stressed) syllable. ${ }^{6}$ The boundaries of a performance rhythm group (further also referred to as 'rhythm group') are determined only by the word stresses and not influenced by the alternation of musical harmonies or the movement of melody. The term 'musical metrical unit' designates a category of musical rhythm of the duration of more or less the eight note that usually corresponds to a single syllable (sometimes also half a syllable or two syllables) in the line. The patterns of performance rhythm structures indicate the number of units in the performance rhythm groups, and the groups are divided by hyphens, e.g., 2-3 (sais-ta / kot-ta-lõ 'I come to you', see Example 1 below). In the examples, the syllables are hyphenated, and hyphens are also used to indicate the stretching of a (linguistic) syllable over two musical metrical units - two song syllables (e.g., when aas-ta is sung as a-as-ta or vaht-rõ-hõ is sung as $v a-(a) h t-r \tilde{o}-h \tilde{o})$. The two syllables that have been sung faster, during a single metric unit, are presented in square brackets [u-mah].

The number of possible combinations of performance rhythm groups is limited and the way a song line is split into rhythm groups depends on the linguistic structure of the line and the choices about the positioning of words by the performer within the limits of the system: e.g., the line tuulo anni nuu ando 'I gave these gifts to him' with syllabic structure 2212 can be sung as follows: tuu-lõ / an-ni nuu / an-dõ (the performance rhythm structure is 2-3-2) or tuu-lõ / an-ni nuu / a-(a)n-dõ (2-3-3) or tuu-lõ / an-ni / nu-u / an-dõ (2-2$2-2)$ - in Q3 words nuu and andõ, one syllable is sung sometimes over one, sometimes over two musical metrical units).

6 In speech, the somewhat irregular alternation of stressed and unstressed units is caused by natural language rhythm, the division of the speech flow into feet - speech units lasting from one stress to another (Asu et al. 2016: 126). In the Estonian language, a foot is formed of a stressed (incl. secondary stress) syllable, followed by one or two unstressed syllables, whereas the described alternation of stress entails also monosyllabic words (Ibid.: 127, 153-154). For language historical reasons, in Southeast-Estonian dialects, a Q3 syllable often builds an entire separate foot (Viitso 2003: 162). 
Musical metrical units are determined on the basis of the choral part of laments. Distinguishing a musical metrical unit is supported by a change in pitch or a perceivable pulsation (the boundary is marked by the dynamics, sometimes with a momentary minimal change in the pitch). If in a choral part the interpretation of the verse in two different ways could be clearly detected, then the two simultaneously sounding musical interpretations were analyzed as two separate structures. The fermata-like musical extensions in death laments do not form a separate metric unit, since these are not independent rhythmic categories that would be proportionate to the main duration (e.g., twice as long). Since the two endnotes of the choral part in bridal laments are systematically sung faster, then in these the metric structure of the line ends has been identified based on how the choir joins the lead singer on the last notes of the lead singer's part - where the two endnotes are not sung faster. Of course, there is always a certain grey area of transitions and subjective decisions made in identifying metrical units (some lines were, in fact, excluded from the analysis because it was impossible to identify which rhythm structure they belonged to). Perhaps, acoustic measuring might help to make the data more accurate, but that would be extremely time-consuming considering the amount of the material. There is, however, enough material to level out possible identification errors in the final result.

In laments, lines of the same lexical composition can be performed with different performance rhythm structures. There is a question whether the performances of the lines with the same linguistic structure but with different musical rhythm should be interpreted (on the level of meter) as separate poetic metrical structures (verse structures) or should the metrical structure be a generalization - and whether this generalization should be based more on the linguistic or the musical level? In our previous studies, we distinguished between musical performance rhythm structure and poetic metrical (verse) structure (Oras, Sarv 2021). In analyzing the laments, we tried to avoid the terms 'poetic metrical structure' and 'stress groups' for the reason that it is not clear whether there is any point in differentiating between the structural levels in laments in the same way as it has been done in refrain songs. If there is, it is still impossible to determine which performance rhythm structures correspond to the same generalized verse structure before the analysis is carried out.

In the discussion part we compare different song groups on the level of poetic metrical structures. The patterns of poetic metrical structures indicate the number of units in the stress groups, and the groups are divided by plus signs, e.g., $2+3+2$. A stress group is as a generalized unit of the level of poetic metrical structure that is based on the musical performance rhythm structure, leaving out of consideration its most varying part (this concerns the shortening method described below). 
Units of stress group are here understood as the verse positions which usually are filled by a syllable (in certain cases also half a syllable or two syllables).

In short, the signs used in the schemes of the different structural levels are as follows:
Syllable structure:
(Ol-li ju-mal-dõ sa-jah
'I was in weddings of gods')
Performance rhythm structure: 2-3-2 (Ol-li/ju-mal-dõ / sa-jah)
Metrical Verse structure:
$2+3+2$

The first and second halves of the lament lines were analyzed separately. In laments, the end of the first half-line is marked by a monosyllabic word (in rare cases also a disyllabic word sung to a single metric unit), which is preceded by an addressing formula in all bridal laments and in some death laments. For example, in the line sullõ kallu, maamakõnõ, ma kaala ümbrelle ('I'm leaning, dear mother, around your neck'), the addressing formula is maamakõnõ ('dear mother') and $m a$ ('I') is the additional syllable connecting the two parts of the line. Neither the addressing formula nor the additional syllable is shown in the performance rhythm patterns given here - the analysis includes the main line, which in laments is at most a 10-syllabic line. Therefore, in the following analysis, the main line of this example is sulló kallu kaala ümbrelle, which is usually performed as follows: sul-lõ / kal-lu // kaa-la / ümb-rel-le (the structure of performance rhythm groups is 2-2 // 2-3). It must be kept in mind, though, that the additional syllable is a structural element, characteristic of the musical structure of Seto laments. ${ }^{7}$

\section{Background: On laments and Seto song metrics}

\section{Seto laments in the Finnic lamenting tradition}

Lament is a poetic, musical and bodily form of self-expression characteristic of transition rituals. Lamenting relieves psychological tensions caused by changes in the social status of a community member. As these changes alter

\footnotetext{
7 Many ethnomusicologists who have described the metric structure of Seto laments have taken into consideration the actually sung texts with an additional syllable (Pino, Sarv 1981; Sarv 2000b, 2000c, Pärtlas 2018). Since one of the aims of our paper is to compare the meter of Seto songs of different structures, it seems practical to do it on the level of the main line, the common part of the different versions of meter.
} 
the structure of the community, lamenting helps to restore its social coherence and reorganize relationships between members of the community and the spheres of the living and the dead (Honko 1974; Nenola 1982; Wilce 2009; Arukask 2011; Stepanova, Frog 2015; Frog, Stepanova 2019). As a universal genre, laments are known in different parts of the world: in Europe, the area in which the tradition has been preserved longer spans from the south of the Balkans to the Slavic and Finno-Ugric peoples in Eastern Europe, in the regions of eastern (Orthodox) rather than western (Catholic) Christianity. This area also covers the region of the lamenting tradition of the Finnic peoples, including that of the Seto on the border of Estonia and Russia (Honko 1974: 13-14; Nenola-Kallio 1982: 16).

The main groups of laments in the Seto tradition are bridal and death laments, although laments have also been sung when sending a young man off to the army. A bridal lament is sung by the bride and her bridesmaids (podruski') before the wedding and in the first part of the wedding cycle. The bride usually sings the lead part, in some cases, however, a bridesmaid or some older woman may perform it instead of her (Sarv 2000a: 19; Hagu 2000: 211). According to the tradition, lamenting is accompanied by constant movements: the bride bows to the people whom she addresses in the lament. The bridesmaids also bow, standing next to the bride in a semi-circle. ${ }^{8}$

Death lament was usually performed solo, although occasionally it may have been performed by a choir: when an unmarried maiden died, her girlfriends lamented at her funeral. While bridal lament used to be an obligatory part of every wedding forming a central genre in the singing culture, choral death lament was a peripheral, rarely used genre, at least in the 19th-20th century.

As is common to many other peoples, lament stands apart from other vocal practices in the Seto tradition. Lamenting (improvising in a lamenting form) is a highly specific activity and a form of self-expression. ${ }^{9}$ At the same time, the structure of Seto choral laments (both bridal and death laments) is almost as stable as the structure of Seto runosongs; in this respect, choral laments are more similar to choral songs than death laments performed solo. Pointing to the musical similarity between Seto choral wedding laments and wedding songs, Vaike Sarv argues that "bridal lament differs from other wedding songs

8 Example available at https://youtu.be/k-5Lz_p5Ey4?t=334 (00:05:34).

9 The same applies to the solo laments of other Finno-Ugric peoples - the Finnic peoples, Mordovians, and Udmurts (whose improvisational vocal genre of krez has some functions of laments), as well as Russians (the developed lament culture is especially characteristic of the northern part of Russia) and Lithuanians as representatives of Baltic lament tradition. 
mainly in its function" (Sarv 2000c: 163$).{ }^{10}$ In addition to the function, laments performed by a choir are clearly different from other songs because of the specific manner in which they are performed (the difference is more obvious in death laments).

The similarity between Seto laments, especially choral laments, and runosongs has been previously underlined by all researchers who point out the difference of the Seto tradition from the northern Finnic lamenting tradition and inquire about the evolution of this style of lamenting. ${ }^{11}$ In the Seto region, laments and songs share the strongest similarities; it is the only Finnic area, in which laments have a stable metric structure and, next to solo laments, also choral laments are common. A Seto researcher Paul Hagu finds Seto bridal laments "as almost identical with runosong both in poetics and form". Hagu justifiably argues that there is a difference in their verse structure, but it is so slight that "matching the runosong line of verse to the lamenting meter is not a problem for any Seto female singer" (Hagu 2000: 216, 225). The verses and motifs of laments and songs overlap - the majority of lament verses have direct parallels in songs and, according to Kristi Salve, there are very few of such traditional motifs that can be found only in laments (Salve 2000).

Paul Hagu has suggested that since the laments of other Finnic areas are performed solo, "Seto bridal lament must have evolved to choral singing already in the Seto region, in certain isolation," even though it may have happened a lot earlier than over the past few centuries (Hagu 2000: 226). Kristi Salve has proposed two possible courses of development for Seto lament: "Current understanding does not allow us to speculate whether Seto lament

10 In Estonia (outside of Setomaa) only few examples of death laments are recorded from eastern region (Pino, Sarv 1981). In the Estonian wedding tradition a cycle of runosongs, sung when sending the bride away from home, function as laments, but they were not performed differently from the other runosongs and were not considered laments by either the performers or the researchers (Tedre 2000).

11 The songs and laments that share the least resemblance are those of Archangel Karelia. The laments are characterized here by a separately evolved language of metaphors and unmetered long multiphrasal lines (Stepanova 1985, Konkka 1985, Stepanova 2017, Frog 2019). In southern Karelia, and especially in Ingria, laments are more similar to songs both in contents and form, but they are still basically unmetered (Honko 1974; Nenola 1982, 2002). In the musical tradition of Finnic laments, southern Vepsian laments have the most simple monophrasal structure, and are considered to be the most archaic examples of Finnic laments by Ingrid Rüütel (Rüütel 2000). Musically similar to the latter are Izhorian, Votic and Seto tunes of (solo) laments, the scale of which also consists of 3 to 4 successive notes, which are sung syllabically with a descending melody, whereas their structure is slightly more complex. Karelian lament tunes have a larger musical range and their structure is the most complex, representing a later stage of musical thinking (Rüütel, Remmel 1980; Krasnopolskaya 1980, 1986; Niemi 2002). 
became what it is now through a slow course of development, in parallel with singing, or - which is more likely - the early lamenting style was thoroughly reformed on the example of the once established runosong" (Salve 2000: 71). Vaike Sarv has regarded the metrics of laments as "pre-runosong", considering the archaic nature and constant practicing of the lamenting genre, although in a following explanation, she has pointed out its relation with runosong: Seto lament metrics is a result of "the parallel development of some elements of runosong in the area influenced by Baltic and Slavic contacts" (Sarv 1993: 292; 2000c: 161).

\section{The musical structure of Seto laments}

Vaike Sarv and Žanna Pärtlas have studied the musical side of Seto choral laments. Sarv investigated the tunes of bridal laments focusing on the lead singer's part (Sarv 2000b, 2000c); Pärtlas analyzed in more detail the tune types of choral death laments on the basis of the polyphonic choral part (Pärtlas 2018). ${ }^{12}$ While both scholars agree that the poetic and musical structures of all Seto lament types share similar features, Pärtlas, when comparing the tune types of choral bridal and death laments, also noticed essential differences between them. For example, regardless of the small number of recordings, choral death laments have been performed to various tune types, whereas bridal laments, which were more widely spread, had one established tune type. The following description of lament tunes relies largely on the study by Pärtlas (2018).

The tunes of choral laments, in terms of style, are part of an older layer of Seto multipart singing, which is characterized by an unusual ancient scale (the so-called one-three-semitone scale), ${ }^{13}$ a single-level rhythmic system in which all notes are structurally of the same length (in performance, the length of the

12 The choral part was preferred because of its stability and for the reason that Pärtlas categorizes tune types according to the alternating rhythm of harmonic complexes (harmonic rhythm).

13 The one-three-semitone scale (in semitones, $1-3-1-3-1$, notated as $\mathrm{D}-\mathrm{Eb}-\mathrm{F} \#-\mathrm{G}-\mathrm{A} \#-\mathrm{B}$ ) is highly rare in traditional music and its origins are so far unclear (Sarv, Jaan 1980; Pärtlas 1997, etc.). The only documented parallels are found in the choral songs of Belgorod region of Russia (South Russia), which is geographically very far from Setomaa (Pärtlas 2005, 2006a). The one-three-semitone scale is typical of the oldest vocal genres of the Seto tradition. This fact and also the intervallic structure of this scale and specific tuning while singing give evidence that here we are dealing with the relict of ancient musical thinking. 
notes somewhat varies), and the text and tune are syllabically related (one note usually corresponds to one syllable).

The textual and musical structure of Seto laments have two components-the main verse and melody line, and the addressing formula. In choral laments, the addressing formula is mostly a quadrisyllabic word in a diminutive form ( $m a a-$ makõnõ 'dear mother', tätäkene 'dear father', velekene 'dear brother', sõbrakõnõ 'dear friend', etc.); in laments performed solo, the quadrisyllabic addressing formula is often extended by adding a disyllabic word (e.g., kuku maamakõnõ 'dear mother'). The main melody line divides into two, and the first part has a stable musical structure, consisting of two performance rhythm groups based on word stress - a 2-unit group is followed by 3-unit group. For aligning the main verse with a 3-unit group, a structural additional syllable is used, which is highly typical of Seto singing (e.g., kur-val / mee-lel $\underline{m a}$... 'in sorrow, I ...). This additional syllable produces a mandatory caesura in the line and can be interpreted as an anacrusis to the second half-line. The addressing formula may be located before the main melody line (sõbrakõnõ, sõbrakõnõ, sinno veeme $\underline{\boldsymbol{m i}}$ vällä viimätsestä 'dear friend, dear friend, we'll take you out for the last time') or inside the main line immediately preceding the additional syllable (sullõ lää, maamakõnõ, ma ligi lähkohe 'I'm going, dear mother, very close to you'). The second part of the melody line varies in length and structure, consisting of 4 to 6 musical metrical units (syllable-notes), which depending on the position of word stress, are grouped differently, forming 2- and 3-unit rhythm groups (additional syllables are not used in the second half of the line).

In bridal laments and the most typical tune type of choral death laments (see Examples 1 and 2), the addressing formula as if disrupts line at an "inappropriate" moment - before the additional syllable. Such positioning of the addressing formula leaves the impression of "confused" emotional speech. The additional syllable, which now follows the addressing formula, acquires a new function as a connecting syllable, which depending on the manner of performance (the use of a rhythmic stop at the end of the addressing formula), may auditorily become part of the end of the addressing formula or the beginning of the second half-line as a kind of an anacrusis or pickup (although in terms of the main musical structure it is not part of the second half-line). Regardless of the location of the addressing formula, the textual and performance rhythm structure of the main line remains the same, which allows referring to this line as a unique Seto lamenting line.

The tune types of bridal and death laments are very similar in their formal structure and rhythmic model. Their harmonic rhythm (the rhythm of alternating harmonic complexes), however, differs considerably, suggesting the use of different tune types. Folk singers are well aware of the difference and 
never mix up the tunes of a bridal and a death lament. The bridal and death laments are also distinctive in the manner of performance - in death laments, the endnotes of the motifs are extended, resembling sighs (see the circled notes in Example 2), whereas in bridal lament, the final pair of syllabic notes in a line is performed in accelerated manner.

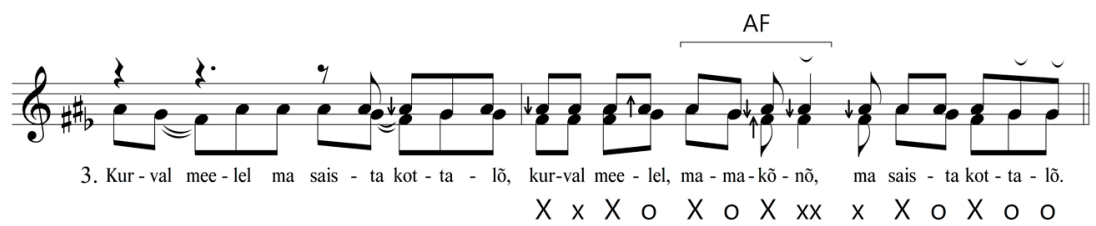

Text structure

Lead singer:

Kur-val mee-lel

Choir:

Kur-val mee-lel, maamakõnõ,

ma // sais-ta kot-ta-lõ

ma // sais-ta kot-ta-lõ

In sorrow

I // come to you

In sorrow

dear mother

I // come to you

Example 1. Lines of lead singer and choir of a bridal lament performed by Jekaterina Lummo with the choir, Värska parish, 1990 (RKM, Mgn I 59 (7)). The harmonic rhythm is indicated below the choir part - the rhythm of two alternating harmonic complexes (marked by symbols $\mathrm{O}$ and $\mathrm{X}$ ), AF designates the addressing formula. (Translation: 'I'm coming to you in sorrow, dear mother'.)

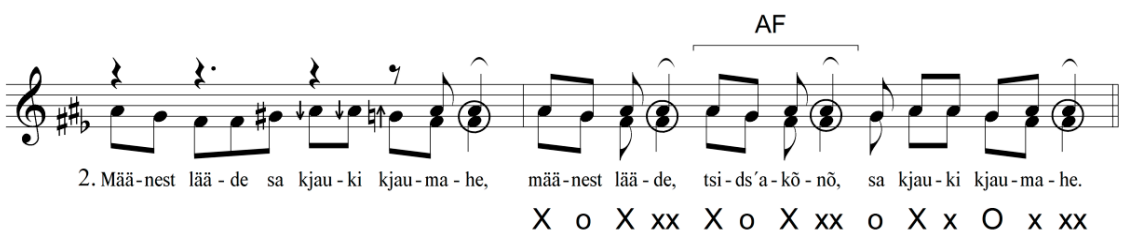

Text structure

Lead singer: $\quad$ Mää-nest lää-de

Choir:

Mää-nest lää-de, tsi-ds'a-kõ-nõ,

sa // kjau-ki kjau-ma-he

sa // kjau-ki kjau-ma-he

What journey are

What journey are, dear sister

you // going on

you // going on

Example 2. Lines of lead singer and choir of a death lament for a young woman, performed by Maria Sirel with the choir, Serga parish, 1972 (KKI, RLH 72: 5(1)). The harmonic rhythm is indicated below the choir part - the rhythm of two alternating harmonic complexes (marked by symbols $\mathrm{O}$ and $\mathrm{X}$ ), AF designates the addressing formula. The circled notes indicate the extended endnotes of motifs. (Translation: 'What journey, dear sister, you are going on?') 


\section{Previous studies on the metrics of Seto laments}

The metrics of Seto laments has been previously described by an Estonian ethnomusicologist Vaike Sarv (1986, 1993, 2000b, 2000c) and folklorist Paul Hagu (2000). Both have proceeded in their analysis from the musical performance of laments.

Vaike Sarv carried out a statistical analysis of metrical structures in the lead singer's part of bridal laments and in death laments performed solo. She described the metrical system of a lament as an accentual system, in which a stressed syllable that starts 'a foot' or 'stress group' ${ }^{14}$ may be followed by a different number of syllables (Sarv 1986: 278-279; 2000b: 127, the following examples are taken from the studies of bridal laments, ibid.: 130, the slashes separate the feet, as delimited by Vaike Sarv, see also fn. 16 below):

\begin{tabular}{|c|c|}
\hline$P e-r \ddot{a}-/ m \ddot{a}-n e$ & $\begin{array}{c}\text { mul // om-mõ / ik-mi-ne (2 / } 3 \text { / } 2 \text { / } 3 \text { syllables) } \\
\text { ('For the last time I'm crying') }\end{array}$ \\
\hline Näi-o / sul-lõ & ma // ku-mar-da / jal-ga (2 / 3 / 3 / 2 syllables $)$ \\
\hline & ('I, maiden, before you I prostrate myself') \\
\hline Hii-rol / la-sõ_ks & siin // hil---lä / min-nä (2 / 3 / 2 / 2 syllables) \\
\hline & ('Let the horse, here, ride slowly') \\
\hline Sui-ku_ks / tu-lõ_s & $\begin{array}{c}\text { mul // suu-ri / sui-ga-tõn-na (2 / } 3 \text { / } 2 \text { / } 4 \text { syllables) } \\
\text { ('I didn't have a big sleep') }\end{array}$ \\
\hline
\end{tabular}

The second unstressed syllable of the second foot is an additional syllable - a monosyllabic word (very rarely a disyllabic word sung to a single musical metrical unit) that Sarv refers to as a connecting word (cf. Hagu's term 'transitional syllable'). A lament line most often includes 9-11 syllables (the additional syllable included but without an addressing formula).

Vaike Sarv described the metrics of laments as a homogenous system which applies to both bridal and death laments. Sarv demonstrates certain ambiguity in her arguments, apparently caused by dissimilarities in the textual features, and especially the musical performance, of the lines of bridal and death laments. Since the end of the choral part in bridal lament is performed faster, the issue whether the number of feet in a lament is always four or could

\footnotetext{
14 In her first studies Vaike Sarv has used the term 'foot' - not in the meaning of metrical feet that form a trochaic tetrametric rhythm of runosong, but in the meaning of accentual meter, as the group of syllables formed by a stressed syllable and unstressed syllables following it. Later she used the term 'stress group' instead of 'foot. The term 'stress group' used by Vaike Sarv corresponds to the term 'performance rhythm group' used here (see Material and methods).
} 
it sometimes be five remains unresolved. Sarv seems to acknowledge that a death lament may have a fifth foot / stress group (1993: 292; 2000b: 127). However, in bridal laments, the use of a fifth foot is "avoided with various devices" (ibid.) - under these devices, she means an accelerated performance of syllables in 6-syllabic second half-line. ${ }^{15}$ At that, Vaike Sarv has also argued that the second half-line of a bridal lament is relatively stable in terms of duration. To achieve that, the syllables are either performed in an accelerated form in a 6-syllabic half-line or more slowly in a 4 -syllabic half-line. ${ }^{16}$

In analyzing the quantity degrees of the initial syllables in lament lines, Vaike Sarv distinguished between the short (Q1) and long (Q2 and Q3) quantity degrees, as was common in the study of runosong metrics at the time - the independent metric quality of the quantity degree of Q3 in Southeast-Estonian verse, including Seto verse, was recognized only in later studies (Mari Sarv 2008, 2015; Oras, Iva 2017). Neverthless, Vaike Sarv measured the acoustic length of vowels (all, not only initial syllables) in the lines of the lead singer of a bridal lament, and the results of this work suggest a clear difference in the vowel length of Q3 syllables compared to syllables in Q1 and Q2: the vowel length of syllables in Q1 was approx. 70-100 milliseconds, in Q2 it was 140-180 milliseconds, and in Q3 about 340-380 milliseconds (2000b: 139).

Paul Hagu employed a heuristic approach in describing the verse structures of the choral part of bridal lament. Having grown up in the tradition, Hagu demonstrates how he, as a member of the choir, would interpret in the choral part the lines of the lead singer which have a more varied structure and a larger number of syllables than the choral part. Indeed, the solutions he proposed in the article do correspond to the traditional way words are positioned in laments in the archival recordings. He also pointed out the tendency that applies to all the verse structures of a bridal lament to sing the end of the choral part, especially the final foot, with a faster rhythm (Hagu 2000: 220).

15 In her thesis Vaike Sarv mentions a 2-part end group: "in the musical performance, the fifth stress group is merged with the fourth", "thus combining a two-part end group, in which the final syllables are compressed together into the boundaries of a single rhythmic unit" (Sarv 2000c: 155-156, a revised version of Sarv 1993).

16 This is indicated in the above example of a $2 / 3 / 2 / 2$ syllable verse with lines marking the extended syllable in the word hil---lä. While some musical transcriptions of the lead singer's part of the bridal lament in this publication (Sarv 2000b: 130, 156-177) seem to confirm the argument about the extended first syllable/note of the 4-syllabic end part in a musical performance, others do not. 
Hagu offers an alternative interpretation of the metric structure of laments to that proposed by Vaike Sarv. He identified verse structures based on the intuitively determined musical stress: in the typical melodic end formula of a bridal lament tune (in the performance of a lead singer and most of the choir singing the torrõ part) A\#-G-F\#-G-G he places the music stress on A\# and on the last but one $\mathrm{G}$ (in Example 3 these notes have been circled; $\mathrm{cf}$. also Sarv 2000b: 152). ${ }^{17}$ Paul Hagu also interpreted these musical stresses that are not always consistent with lexical stresses as the stresses of poetic meter.

17 Since musical stress is a complex and often ambiguous phenomenon, which may be perceived differently by people of various cultural backgrounds, the positions of stresses proposed by Hagu can be contested. However, there is indeed an analytical consideration that supports positioning the line's last musical stress on the second to the last note of the lament tunes. This consideration takes into account the above-mentioned phenomenon of harmonic rhythm typical of the Seto multipart songs. E.g., the endings of melody lines of the length of five musical metrical units are characterized by the harmonic rhythm pattern XOXOO in bridal laments and XXOXX in death laments (see Examples 1 and 2; corresponding melody variants of the main voice are e.g. A\#-G-F\#-G-G and A\#-A\#-G-F\#-F\#). In both cases, the tune arrives at the last "tonic" function on the last but one syllable-note, which creates a harmonic accent. Interestingly, this harmonic accent does not coincide with the beginning of the last 3-syllabic stress group of the text. The research on the harmonic rhythm in Seto songs reveals that such a contradiction in this style is rather exceptional (Pärtlas 2001). Here it is possible to draw a parallel with the performance of the line structure $2+3+3$ ( 8 syllables=positions, word stresses on the 3 . and 6 . position) in the songs of stable length: when performing the $2+3+3$ line structure, the harmonic (melodic) accent on the last but one note does not coincide with the word stress on the third note from the end and, as a result, the same contradiction emerges as in the laments. 
a)

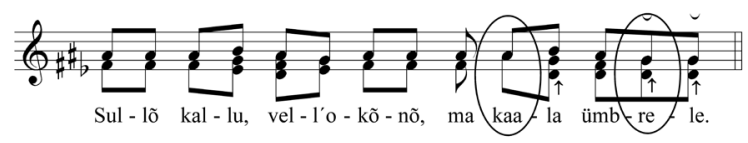

b)

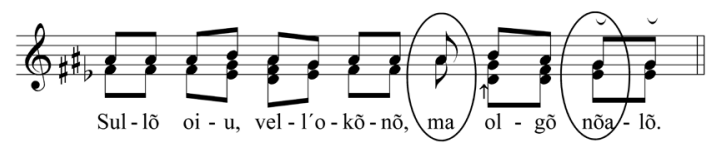

a) sul-lõ kal-lu, vel-l'o-kõ-nõ,

ma // kaa-la ümb-/rel-le

('I'll hold you, dear brother, around your neck')

b) sul-lõ oi-u, vel-l'o-kõ-nõ,

// ma ol-gõ / nõa-lõ

('I'm leaning, dear brother, upon your shoulders')

Example 3. The stresses of poetic meter in the choral part of bridal laments that Paul Hagu identified on the basis of musical stresses. The musical/poetic metric stresses in the second half-line have been circled. a) The metric structure, the end part of which Hagu interprets as placing the initial linguistically stressed syllable of the word in the metrically unstressed position of the line (here on the word ümbrelle); b) The metric structure, in which, according to Hagu's interpretation, the additional syllable preceding the second half-line is given a musical/poetic metric stress and thus "the position of the transitional [additional] syllable remains empty" (Hagu 2000: 223). Transcriptions of recording ERA, PI 25 B2.

Since in the second half-line of bridal laments musical ending formulas coincide in the performance of different linguistic structures, according to Paul Hagu, the initial syllables of polysyllabic words do not always align with the position of musical/poetic metric stress, but may fall on an unstressed position (Example 3a). ${ }^{18}$ Hagu argues that if the second half-line consists of four syllables, the structural additional syllable is transferred to the "rise of the verse foot" (it is not sung on the usual F\# note, preceding the A\# note, but on the A\# note, which, according to Hagu, designates both the musical and poetic metric stress) and, in this case, the position of the additional syllable remains empty (Example 3b).

18 This follows the example of runosong verse, as in regional traditions in which the quantity of the stress syllable is taken into account it is common and natural that short stressed syllables fall on unstressed (or weak) positions in the metric pattern. In his work, Paul Hagu does not touch upon syllable quantity. 
Paul Hagu views the following pattern as the "metrically ideal line of bridal lament": x 1 - x 1 - addressing formula - 1[additional syllable] // x 2(3) - x 1 (in the pattern, $x$ indicates poetic metric stress (not word stress), and numbers indicate metrically unstressed syllables, which sometimes also include the linguistically stressed syllables of words). Considering all the possible deviations, the pattern would be: $\mathrm{x} 0 / 1 / 2-\mathrm{x} 0 / 1 / 2$ - addressing formula - 0/1/2 - x 2/3 - x 0/1 (Hagu 2000: 224).

\section{On Seto runosong metrics}

In the comparison of the metrics of Seto laments and that of Seto runosongs, we rely on our previous studies on two runosong corpora: the lyrical and epic songs sung to the feast tune, of stable length (577 lines) and the harvest, wedding and game songs with a refrain and varying line length (1,150 lines; Oras, Iva 2017; Oras 2019; Oras, Sarv 2021). Like laments, these songs are sung to tunes belonging to the older type, which consist of notes belonging to a single length category. The analysis explores the level of the main line in the choral performance (excluding repetitions and additional syllables) and identifies verse structures - combinations of stress groups. Here we have adopted the term 'stress group' to describe verse structure according to regular patterns in the alternation of (linguistically) stressed and unstressed units (see Material and methods). There are two structures in the songs with a stable melodic line length (the number of musical metrical units): $2+2+2+2$ lines and $2+3+3$ lines (83.2\% and $16.8 \%$, respectively, see Table 1 ). 
Table 1. The share of different verse structures in refrain songs and songs using the feast melody (Oras, Sarv 2021). In the schemes of poetic metrical structures, the stress groups are separated by the plus signs (+), in the schemes of musical performance rhythm structures the performance rhythm groups are indicated by hyphens (-).

\begin{tabular}{|c|c|c|}
\hline Verse structure & Refrain songs & Songs using the feast melody \\
\hline $\begin{array}{l}2+2+2+2 \\
\text { two performance rhythm } \\
\text { structures in refrain songs }\end{array}$ & $\begin{array}{l}958(83.0 \%) \\
\begin{array}{l}\text {..-2-2-2 }-58.4 \% \\
\ldots-2-3-24.6 \%\end{array}\end{array}$ & $480(83.2 \%)$ \\
\hline $2+3+3$ & $146(12.7 \%)$ & $97(16.8 \%)$ \\
\hline $2+3+2$ & $35(3.0 \%)$ & - \\
\hline $2+2+3$ & $11(1.0 \%)$ & - \\
\hline $3+2+3,3+3+2$ & $4(0.3 \%)$ & - \\
\hline Total no. of lines & $1150(100 \%)$ & $577(100 \%)$ \\
\hline
\end{tabular}

In refrain songs, the main line is sung over 8 or 7 musical metrical units. The initial stress group may be extended by a structural (i.e. obligatory) or occasional additional syllable in musical performance. ${ }^{19}$ In this song group, we differentiated between two structural levels - the poetic metric structure (consisting of stress groups) and that used in a musical performance (consisting of performance rhythm groups). The differentiation of structural levels proved useful in terms of the $2+2+2+2$ verse structure, which has been presented in two ways: as groups of two notes, or 2-unit performance rhythm groups (2-22-2, e.g., kuv-võ / pruu-di / ko-(o)t- / ta-lõ 'in the place of six brides'; sääl-tä /

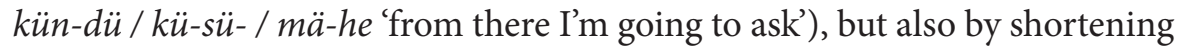
the end part, "compressing" the final two 2-unit stress groups into a 3-unit performance rhythm group (2-2-3, e.g., kuv-võ / pruu-di / kot-ta-lõ; si-nult

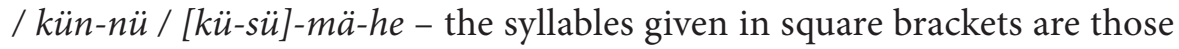
"compressed" together, sung twice as fast). ${ }^{20}$ Such lines shortened during the performance constitute one-fourth of all the lines. At the same time, different singers do not use shortening in equal measure. While Anne Vabarna, one of the best-known Seto singers, hardly ever uses it in refrain songs, there are

19 In a harvest song with a longer tune, mentioned above, there are two extra line-initial syllables.

20 Refrain songs contain a few lines with the $2+2+3$ structure (Table 1, fourth row), in which a word with a short (Q1 or Q2) initial syllable starts the final stress group, which can be sung only to the performance rhythm structure of ...-2-3. 
singers who have adopted it as the main way of performing the lines with the corresponding linguistic structure, and here the influence of lamenting may be speculated (Oras 2019).

The statistics of the quantity degrees of the two analyzed runosong groups only concerns the lines performed with 3-unit performance rhythm groups. The linguistic composition of the lines performed to the ...-2-2-2 performance rhythm has not been further revealed, containing only a remark that here the initial words of the stress groups may be in all three quantity degrees. Among the lines of 3-unit stress groups, in the most popular, $2+3+3$ structure, the final 3-unit group does not open with Q3 initial syllables, but a few Q3 initial syllables can be found in the third position of the main line (in this case, the 3-unit group is formed of the syllable structure 21, e.g., kan-ni (ta) / at-ra ilm / kaa-bul-da 'he ploughed without a hat'). In the more rare metric structures $2+3+2$ and $2+2+3$ of seven positions, Q3 initial syllables can be found only at the beginning of the last 2-unit group of the 2+3+2 structure (Oras, Iva 2017: 187-188, 191).

When analyzing the runosongs of the Vorrumaa region, the neighboring county of Setomaa, Mari Sarv discovered that here the overlong (Q3) initial syllable has acquired a distinctive metric quality - Q3 initial syllables or monosyllabic words are often stretched over two metric positions (Sarv 2015: 11, 14). ${ }^{21}$ This principle also applies in the analyzed Seto runosongs: monosyllabic words and the Q3 initial syllable of a disyllabic word is quite often stretched over two musical metrical units. In the case of Q1 and Q2 words, only the final syllable is sometimes divided over two metric units. At the same time, only two initial syllables of Q1 and Q2 words are in some cases sung twice as fast, "compressed" together to a single metric unit, but never those of Q3 words (Oras, Iva 2017: 182-184, 187).

\footnotetext{
21 This phenomenon is rooted in the historical shortening of the words. Several Q3 words are formed as a result of syncope following the stressed syllable; the second syllable of such Q3 words can start a new linguistic as well as metric foot, as in the case of poi-si-kõ-nõ > pois-kõ-nó ('dear boy') (Sarv 2011: 334-335; Pajusalu 2014: 582-583). It seems that, at least in case of southern Estonian songs, the change of the quantity system in language resulted in reconfiguring the metrical structure as well (Sarv 2015, 2019).
} 


\section{Results of the analysis}

\section{Structures of performance rhythm}

In the first half-line of choral laments, the syllables that are part of the main verse are always performed for the duration of 4 musical metrical units (the 2-2 structure). If an additional syllable immediately follows the half-line (without a preceding addressing formula), it forms part of the second performance rhythm group.

The performance rhythm structures occurring in the second half-line of choral laments are given in Table 2 . The proportionally largest share of structures is those consisting of 5 musical units - 3-2 and 2-3, the latter being the most common one. While the share of the 3-2-structure is quite similar in both genres (about one-fourth of all lines, constituting 20\% in bridal laments, cf. Sarv 2000b: 131), ${ }^{22}$ the shares of other structures in these two lament genres reveal a preference for shorter lines in bridal laments and longer lines in death laments. The 2-3-structure is mostly predominant in bridal laments, in which longer 6-unit structures cannot be found. In death laments, the 2-3-structure is encountered half as often as in bridal laments; however, the longer, 2-2-2-structure lines are statistically prevalent among death laments. The shortest, 2-2-structure is quite rare in death laments but is fairly often found in bridal laments.

Table 2. The performance rhythm structures of the second half-line of choral laments, shown in total and separately for both genres (B - bridal laments, D - death laments).

\begin{tabular}{|c|c|c|c|c|c|c|}
\hline Performance rhythm structure & Total & $\mathrm{B}$ & $\mathrm{D}$ & Total\% & $\mathrm{B} \%$ & $\mathrm{D} \%$ \\
\hline $3^{*}$ & 26 & 26 & 0 & 3.5 & 6.0 & 0.0 \\
\hline $2-2$ & 60 & 52 & 8 & 8.2 & 12.0 & 2.7 \\
\hline $3-2$ & 179 & 89 & 90 & 24.3 & 20.5 & 29.9 \\
\hline $2-3$ & 352 & 268 & 84 & 47.8 & 61.6 & 27.9 \\
\hline $2-2-2$ & 116 & 0 & 116 & 15.8 & 0 & 38.5 \\
\hline $3-3$ & 3 & 0 & 3 & 0.4 & 0 & 1.0 \\
\hline Total & 736 & 435 & 301 & 100 & 100 & 100 \\
\hline
\end{tabular}

22 In the statistics based on more extensive sources (1,522 lines of lead singer's part of bridal laments), provided by Vaike Sarv, the percentages are more or less the same: $15 \%$ of the halflines with $\mathrm{xx} x \mathrm{x}$ verse feet (in the current analysis the performance rhythm structure 2-2); $20 \%$ $\mathrm{xxx} \mathrm{xx}(3-2) ; 42 \% \mathrm{xx} x \mathrm{xx}(2-3) ; 20 \% \mathrm{xx} \mathrm{xxxx}$ - here, the initial syllables of the last verse foot are sung faster (in the current analysis also the 2-3 structure) - Sarv 1986: 278-279. (Here ' $x$ ' indicates a syllable, a group of syllables - a verse foot of an accentual system. In her more recent articles, Vaike Sarv used the term 'stress group' instead of 'verse foot', cf. Sarv 2000b: 131.) 
* The 26 addressing verses of bridal laments, with only 3 syllables and corresponding musical metrical units in the second half-line (kaligo, 'dear') form an exception.

Structures in which a mono- or a disyllabic word is sung on the 3 rd musical metrical unit of the five-unit half-line (mostly the syllable structures 212 and 222) are considered as 3-2 (in 19 lines) or 2-3 structures (in 28 lines).

\section{Syllable structures}

\section{The first half-line}

The first half of the main line consists of 2-4 syllables (Table 3). Quite often, in 226 out of 736 cases, or in almost a third of the cases, the amount of syllables is smaller than 4 , which is the constant number of corresponding musical metrical units. Therefore, in performance, one syllable is often divided between two musical metrical units. There are no significant differences between the two lament genres.

The content of the first half-lines is also rather "sparse": the first rhythm group is completed by a semantically light word in $20 \%$ of examples and including a semantically light syllable in another $40 \%$, while the second rhythm group exhibits a comparable proportion of semantically light words. In the first rhythm group, there are 142 monosyllabic words that are divided between two musical metric units. Here the nearly asemantic word noo oo ('well, oh, now'), functioning as a metrical filler but also as a discourse marker indicating the onset of a sequence of lines on a new theme occurs 29 times. Other words with similar functions are $k u i$ ('if'), which occurs 35 times, siis ('then') 8 times, tuu ('this') 7 times, and seo sjoo ('that') 7 times. Of the 54 monosyllabic words in the second rhythm group that are divided between two metric units, the nearly asemantic words viil ('yet, again') and võe või ('or') occur 27 and 3 times, respectively. The proportion of semantically light words is significant (compared to the second half of the line). In our previous study analyzing the longer version of harvest song with the refrain of similar musical structure, we suggested that the beginning part of the line (preceding the additional syllable), sung with 4 musical metrical units, could be tentatively interpreted as including additional syllables that were initially not part of the main verse. The interpretation is supported by the fact that there also exists a shorter version of the harvest song, which has only 2 metric units at the beginning preceding the additional syllable: the longer one no-o kä̈i-ge ti kul-la käe-ke-se; the shorter kä̈ï-ge ti kul-la käe-ke-se ('(well,) move, you dear hands', $t i$ 'you' is the additional syllable). Although in laments all the four positions of the first half-line are conventionally filled, the light semantic load of the first half line supports a hypothesis that historically it has been formed 
by extension of the original (shorter, i.e. octosyllabic) verse line. This assumption is also indirectly supported by the structure of solo laments, in which, according to Vaike Sarv, the first verse foot (here the first performance rhythm group) sometimes remains unoccupied (Sarv 1993: 289).

Table 3. All syllable structures in the first half of the main verse of laments - number and occurrences in both lament genres, shown in total and separately ( $B$ - bridal lament, D - death lament). (The Table shows linguistic syllables, not the so-called song syllables which are the result of the division of a long syllable between two musical metrical units.)

\begin{tabular}{|c|c|c|c|c|c|c|c|}
\hline $\begin{array}{l}\text { The no. of } \\
\text { syllables }\end{array}$ & $\begin{array}{l}\text { Syllable } \\
\text { structure }\end{array}$ & Total & B & $\mathrm{D}$ & Total \% & $\mathrm{B} \%$ & $\mathrm{D} \%$ \\
\hline \multirow{2}{*}{2 syllables } & 2 & 1 & 1 & 0 & 0.1 & 0.2 & 0.0 \\
\hline & 11 & 13 & 7 & 6 & 1.8 & 1.6 & 2.0 \\
\hline \multicolumn{2}{|c|}{2 syllables in total } & 14 & 8 & 6 & 1.9 & 1.8 & 2.0 \\
\hline \multirow{4}{*}{3 syllables } & 3 & 42 & 35 & 7 & 5.7 & 8.0 & 2.3 \\
\hline & 12 & 126 & 63 & 63 & 17.1 & 14.5 & 20.9 \\
\hline & 21 & 39 & 21 & 18 & 5.3 & 4.8 & 6.0 \\
\hline & 111 & 5 & 4 & 1 & 0.7 & 0.9 & 0.3 \\
\hline \multicolumn{2}{|c|}{3 syllables in total } & 212 & 123 & 89 & 28.8 & 28.3 & 29.6 \\
\hline \multirow{4}{*}{4 syllables } & 4 & 67 & 36 & 31 & 9.1 & 8.3 & 10.3 \\
\hline & 22 & 407 & 252 & 155 & 55.3 & 57.9 & 51.5 \\
\hline & 112 & 12 & 5 & 7 & 1.6 & 1.1 & 2.3 \\
\hline & 211 & 24 & 11 & 13 & 3.3 & 2.5 & 4.3 \\
\hline \multicolumn{2}{|c|}{4 syllables in total } & 510 & 304 & 206 & 69.3 & 69.9 & 68.4 \\
\hline \multicolumn{2}{|c|}{ Total } & 736 & 435 & 301 & 100.0 & 100.0 & 100.0 \\
\hline
\end{tabular}

\section{The second half-line}

If the first half-line contains both semantically significant as well as less or unimportant components, then as a rule the second half of line has more semantic weight. The second half of the line most commonly consists of syllable structures of 5 syllables and 5 musical metrical units (Table 4, cf. Table 2). The share of syllables in half-lines also corresponds to the performance rhythm structure characteristic of each genre - in bridal laments the share of 5-syllabic half-lines is slightly larger than in death laments, but in death laments the percentage of 6-syllabic half-lines is larger than in bridal laments. The share of 4 -syllabic half-lines is relatively similar in both lament genres. There are more 
4- and 6-syllabic half-lines than 4- or 6-unit performance rhythm structures: death laments include 4-syllabic half-lines, whereas the 4-unit performance structure is quite rare there; bridal laments have a significant number of 6-syllabic half-lines, but no 6-unit performance structures.

Table 4. Syllable structures in the second half of the lines in Seto choral laments (syllable structures are listed if there are 10 or more lines in both lament genres together, more rare syllable structures are brought together under'Other'), the number is shown in total and separately for both genres ( $B$ - bridal laments, $D$ death laments). The most cases of trisyllabic half-lines are the addressing lines with the kaligo-ending. (The Table shows linguistic syllables and not the so-called song syllables which are the result of the division of a long syllable between two musical metrical units.)

\begin{tabular}{|c|c|c|c|c|c|c|c|}
\hline $\begin{array}{l}\text { The no. of } \\
\text { syllables }\end{array}$ & $\begin{array}{l}\text { Syllable } \\
\text { structure }\end{array}$ & Total & B & $\mathrm{D}$ & Total \% & $\mathrm{B} \%$ & $\mathrm{D} \%$ \\
\hline \multicolumn{2}{|c|}{3 syllables in total } & 31 & 30 & 1 & 4.2 & 6.9 & 0.3 \\
\hline \multirow{4}{*}{4 syllables } & 4 & 10 & 8 & 2 & 1.4 & 1.8 & 0.7 \\
\hline & 13 & 13 & 6 & 7 & 1.8 & 1.4 & 2.3 \\
\hline & 22 & 81 & 41 & 40 & 11.0 & 9.4 & 13.3 \\
\hline & Other & 9 & 6 & 3 & 1.2 & 1.4 & 1.0 \\
\hline \multicolumn{2}{|c|}{4 syllables in total } & 113 & 61 & 52 & 15.4 & 14.0 & 17.3 \\
\hline \multirow[t]{5}{*}{5 syllables } & 5 & 37 & 13 & 24 & 5.0 & 3.0 & 8.0 \\
\hline & 23 & 241 & 168 & 73 & 32.7 & 38.6 & 24.3 \\
\hline & 32 & 82 & 52 & 30 & 11.1 & 12.0 & 10.0 \\
\hline & 212 & 41 & 22 & 19 & 5.6 & 5.1 & 6.3 \\
\hline & Other & 8 & 2 & 6 & 1.1 & 0.5 & 2.0 \\
\hline \multicolumn{2}{|c|}{5 syllables in total } & 409 & 257 & 152 & 55.6 & 59.1 & 50.5 \\
\hline \multirow[t]{3}{*}{6 syllables } & 24 & 149 & 74 & 75 & 20.2 & 17.0 & 24.9 \\
\hline & 222 & 30 & 10 & 20 & 4.1 & 2.3 & 6.6 \\
\hline & Other & 4 & 3 & 1 & 0.5 & 0.7 & 0.3 \\
\hline \multicolumn{2}{|c|}{6 syllables in total } & 183 & 87 & 96 & 24.9 & 20.0 & 31.9 \\
\hline \multicolumn{2}{|l|}{ Total } & 736 & 435 & 301 & 100.0 & 100.0 & 100.0 \\
\hline
\end{tabular}

A comparison of the data on syllable structures and performance rhythm structures explains why these figures do not correspond to each other (Table 5). While in singing one syllable usually corresponds to one musical metrical unit, in some lines one (in rare cases also two) syllable(s) are sung more slowly - in a way that the syllable is divided between two musical metrical 
units. In some lines, the number of syllables exceeds the number of metric units; there two syllables are sung half as fast, during one metric unit.

Table 5. The performance rhythm structures in the second half-line of laments used in performing the more common syllable structures (10 or more lines in both lament genres together). The cases in which the number of units in a performance rhythm structure is larger than the number of syllables in the half-line are shown in bold; the cases where the number of units in performance rhythm structures is smaller than the number of syllables in the half-line are in bold and italics.

\begin{tabular}{|c|c|c|c|}
\hline \multirow{2}{*}{$\begin{array}{l}\text { No. of } \\
\text { syllables }\end{array}$} & \multirow{2}{*}{$\begin{array}{l}\text { Syllable } \\
\text { structures }\end{array}$} & \multicolumn{2}{|c|}{ Structures of performance rhythm } \\
\hline & & Bridal laments & Death laments \\
\hline \multirow{3}{*}{4 syllables } & 4 & $2-2(8)$ & $2-2(1), 3-2(1)$ \\
\hline & 22 & $2-2(40), 3-2(1)$ & $2-2(6), 3-2(30), 2-2-2(4)$ \\
\hline & 13 & $2-3(6)$ & $2-3(6), 2-2-2(1)$ \\
\hline \multirow{4}{*}{5 syllables } & 32 & $3-2(52)$ & $3-2(28), 3-3(2)$ \\
\hline & 5 & $3-2(13)$ & $3-2(24)$ \\
\hline & 23 & $2-3(168)$ & $2-3(62), 2-2-2(10), 3-3(1)$ \\
\hline & 212 & $2-3(10), 3-2(12)$ & $2-3(7), 3-2(6), 2-2-2(6)$ \\
\hline \multirow{2}{*}{6 syllables } & 222 & $2-3(10)$ & $2-2-2(20)$ \\
\hline & 24 & $2-3(74)$ & $2-3(8), 2-2-2(67)$ \\
\hline
\end{tabular}

In performing death laments, one syllable is often divided between two metric units. For example, the syllable structure 22 occurs quite frequently in death laments, but in most cases, it is not sung for the duration of 4 metric units the first syllable of the word is divided between two metric units and the line is performed with the 3-2 structure. Also, in the case of half-line containing 5 syllables, one syllable can be divided between two musical metrical units in death laments but not in bridal laments. While performing bridal laments one syllable is rarely divided between two metric units; however, the shortening "compressing" two syllables into one musical metrical unit - is the norm in 6-syllabic lines. 


\section{Positioning and performing words of different quantity}

In the following, we will explain how word quantity degree influences the positioning of words with a different number of syllables in the song line. The statistics of words in laments (Table 6) provides a context for the following data. There are far more disyllabic words in laments than there are words with other numbers of syllables in total, the number of mono- and trisyllabic words are more or less the same, and the number of longer, 4- to 5-syllabic words is the smallest. There is a greater number of shorter words in the first half-line than there is in the second half-line; the longer words, on the contrary, are positioned mostly in the second half-line, which includes all 5-syllabic words and the majority of trisyllabic words. In terms of quantity, the number of Q2 words is the largest, followed by Q3 and Q1 words.

Table 6 . The number of words of varying length and quantity in choral laments. The numbers of cases in the first and second half-line are separated by a slash. On the right, the number of words with the corresponding number of syllables is shown in total and separately for the first and second half-line. The old forms with a long initial syllable, in which the syncope and apocope have not taken place, and the words which can be pronounced as either Q2 or Q3 words are shown in separate boxes. Empty cells: there are only monosyllabic Q1 and Q3 words in the language and long as well as Q2 Q3 syllables are possible only in the polysyllabic words.

\begin{tabular}{|l|r|r|r|r|r|r|r|r|}
\hline $\begin{array}{l}\text { No. of } \\
\text { sylla- } \\
\text { bles }\end{array}$ & Q1 & Q2 & Q3 & long & Q2 Q3 & Total & $\begin{array}{r}\text { 1st } \\
\text { half- } \\
\text { line }\end{array}$ & $\begin{array}{r}\text { 2nd } \\
\text { half- } \\
\text { line }\end{array}$ \\
\hline 1 & $8 / 11$ & & $270 / 72$ & & & 361 & 278 & 83 \\
\hline 2 & $277 / 144$ & $588 / 349$ & $125 / 263$ & $20 / 53$ & $6 / 13$ & 1838 & 1016 & 822 \\
\hline 3 & $15 / 61$ & $14 / 43$ & $13 / 150$ & $0 / 94$ & $0 / 2$ & 392 & 42 & 350 \\
\hline 4 & $20 / 95$ & $46 / 57$ & $1 / 9$ & $0 / 1$ & $0 / 0$ & 229 & 67 & 127 \\
\hline 5 & $0 / 32$ & $0 / 5$ & $0 / 0$ & $0 / 0$ & $0 / 0$ & 37 & 0 & 37 \\
\hline Total & $\begin{array}{r}320 / 343 \\
(663)\end{array}$ & $\begin{array}{r}648 / 454 \\
(1,102)\end{array}$ & $\begin{array}{r}409 / 494 \\
(903)\end{array}$ & $\begin{array}{r}20 / 148 \\
(168)\end{array}$ & $\begin{array}{r}6 / 15 \\
(21)\end{array}$ & 2,857 & 1,403 & 1,419 \\
\hline
\end{tabular}

\section{The first half-line}

The system of positioning the words of different quantities and with a different number of syllables is simpler in the first half-lines where shorter words dominate, and the main line is always sung over four musical metrical units (Table 7). 
Monosyllabic words are sung over one or two musical metrical units. Short monosyllabic Q1 words are performed only over one musical metrical unit and are positioned only on the second unit (which can be interpreted as the second verse position). Long monosyllabic Q3 words, performed during one musical unit, belong to the first performance rhythm group. In the second group there are only monosyllabic Q3 verbs with the following negation particle (e.g., saa-ai 'cannot' - 26 cases, syllable structures 111 and 211). As the particle belongs together with the preceding verb, it would be more reasonable to interpret these cases as disyllabic words.

The vast majority of Q3 monosyllabic words are divided between two musical metrical units. The syllables divided between two units are positioned on 1st-2nd or 3rd-4th metric units. In 13 cases, the first half-line consists of two monosyllabic words divided into 4 metric units (e.g., $k u-i / v i-i l$ 'if again').

Disyllabic words are positioned syllabically in the first half-line, regardless of word quantity (except for $k a-o s-/ s i(-i)$ 'I would disappear').

The positioning of trisyllabic words in the first half-line requires dividing one syllable between two musical metrical units. The system here is the same as in the songs: in Q1 and Q2 words the final syllable, and in Q3 words, the initial syllable is divided (Oras, Iva 2017).

Quadrisyllabic words in the first half of the line are Q1 or Q2 words (with one exception), and they are sung syllabically. 
Table 7. The positioning of the words of different quantity degree on the four musical metrical units (notes) in the first half of the song line. The total of corresponding cases is shown in the right column. Q1 and Q2 words are analyzed together since the principles of their positioning coincide. The forms with a long initial syllable, in which the syncope and apocope have not taken place, and the words which can be pronounced either as Q2 or Q3 words (29 cases altogether), as well as 2 exceptions, are not included in the Table.

\begin{tabular}{|c|c|c|c|c|c|}
\hline Monosyllabic & $1 \mathrm{st}$ & 2nd & $3 \mathrm{rd}$ & 4th & Total \\
\hline Q1 & & ma & & & 8 \\
\hline \multirow{5}{*}{ Q3 } & kui & & & & 14 \\
\hline & & sääl & & & 6 \\
\hline & & & saa & as & 26 \\
\hline & \multicolumn{2}{|c|}{ rist } & & & 142 \\
\hline & & & \multicolumn{2}{|c|}{ viil } & 54 \\
\hline \multicolumn{6}{|l|}{ Disyllabic } \\
\hline \multirow{2}{*}{ Q1, Q2 } & säid- & se & & & 407 \\
\hline & & & pa- & nõ & 458 \\
\hline \multirow[t]{2}{*}{ Q3 } & ümb- & re & & & 44 \\
\hline & & & jät- & tä & 80 \\
\hline \multicolumn{6}{|l|}{ Trisyllabic } \\
\hline Q1, Q2 & tu- & lõ- & \multicolumn{2}{|c|}{ va } & 29 \\
\hline Q3 & \multicolumn{2}{|l|}{ kot- } & ta- & 10 & 13 \\
\hline \multicolumn{6}{|l|}{ Quadrisyllabic } \\
\hline Q1, Q2 & hel- & lät- & sil- & le & 66 \\
\hline
\end{tabular}

\section{The second half-line}

In the second half-line with a varying number of musical metrical units, other positioning models are added to the models used in the first half-line.

Here it proved challenging to decide how the half-lines that are sung using five metric units, in which a mono- or disyllabic word is sung during the third metric units (mainly the middle syllable of 212 syllable structure and the middle disyllabic word, sung twice as fast, of 222 syllable structure) should be organized into performance rhythm groups. Mechanically all these could be identified as a 3-2 structure because a monosyllabic word positioned on one musical metrical unit that is followed by a longer word, does not, as a rule, start a metrical unit. But the previous analysis of refrain songs has shown that 212 and also 222 syllable structures (as well as 23 and 24 syllable structures), even if using the exact same lines, may be sung both during the five and six 
metrical units. Considering these alternatives, we regarded in this analysis the following to be a 2-3 performance rhythm structure:

- All second half-lines of the 222 syllable structure in which the middle word is compressed to one metric unit during the performance (10 lines, e.g., ol-la / [u-mah] ko-toh 'to be in my own home');

- These lines of the 212 syllable structure in which (a) Q3 monosyllabic words are content words (12 lines: the words kuus, käest, maa, rüä, suud, vii, mii); (b) a monosyllabic non-content word carries the sentence stress (6 lines: ar koolda - ar 'away', koolda 'die', ar minnä - ar 'away', minnä 'go', sjoost aost tunnist 'by that time' - sjoost 'that', miä tetä 'what to do' - miä 'what'). This principle is supported by the fact that all these monosyllabic words that are sung in the middle group of the 2-2-2 performance rhythm structure during two metrical units (maa 'earth', suu 'mouth', sau 'clay') are also content words.

A line of the 212 syllable structure is regarded as belonging to the 3-2 performance rhythm structure if (a) the monosyllabic word is a short pronoun (11 lines: $m a$ ' $I$ ', $m u$ 'my', $m i$ 'we', $t i$ 'you'); (b) the monosyllabic word is formed of a long syllable but the word is not a content word and does not carry sentence stress (6: joht ' indeed not', küll ' indeed', miä 'that', mul 'I [have]'); (c) the monosyllabic word is the second component of a compound word (2: mar'apuu 'berry tree', vislapuu 'cherry tree').

\section{Monosyllabic words}

A. Sung over one musical metrical unit:

1) The final syllable of the three-unit rhythm group in structure 3-2 (Q1 as well as Q3 words, 19 in total): söö-di, $\boldsymbol{m a} /$ sei-e ('[you] fed me, I ate'); ko-do küll / tul-la ('to come home').

2) The initial syllable in structure 2-3 (only Q3 autosemantic words or words with a sentence accent, 18 in total).

3) The remaining 3 cases are two-unit groups, containing a negation particle (saa-ai 'cannot').

B. Sung over two musical metrical units:

Q3 words, several times in the structures 2-2 (4, all maa-lõ / jä-ä '[I'll]

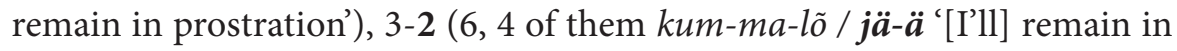
prostration'), 2-3 (11, tu-u / tunn'-kõ-nõ 'that hour'), 2-2-2 (6, $\boldsymbol{m a} \boldsymbol{a}-\boldsymbol{a} / \mathrm{hai}$-su-/ $k \tilde{o}$-sõ 'the smell of the earth'), 2-2-2 (6, mõ-sõ / $\mathbf{m a}$-a / lõh-na ' [I'll] wash away the smell of the earth'), 2-2-2 (3, ti-i / poo-lõ / päa-äl 'midway'); only once in the structures 2-2, 3(2-1)-2 and 2-3(1-2) (39 in total).

\section{Disyllabic words}

Table 8 shows the share of disyllabic words in different performance rhythm structures of the second half-line. In the second half-line, the share of Q1 words is $17.5 \%$, Q2 words $-42.5 \%$, Q3 words $-32.0 \%$ and other cases $-8.0 \%$. 


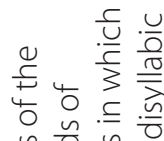
凹ั 음 产方远 u․ㅡㄹ 总造至的 $\varepsilon$ ह ह टे षेष ते है है है ब 웡 흘

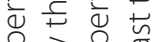
궁

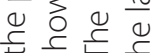
( o 年 낭ㅎㅇ

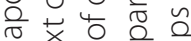

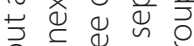
응 항

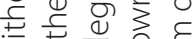
3

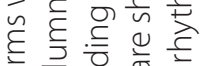
희응 흥

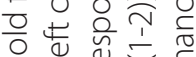
等

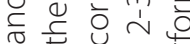

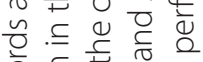

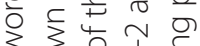

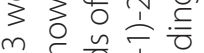
\% 든 응 흘

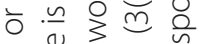

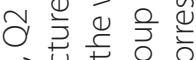
ris 要

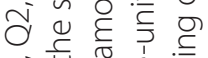
$\overline{0} \subseteq \square$

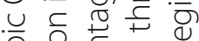

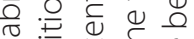
年

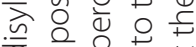
年

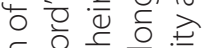

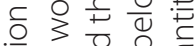

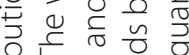

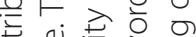

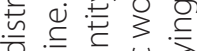
势

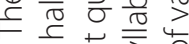

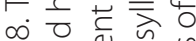
o

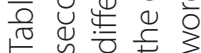

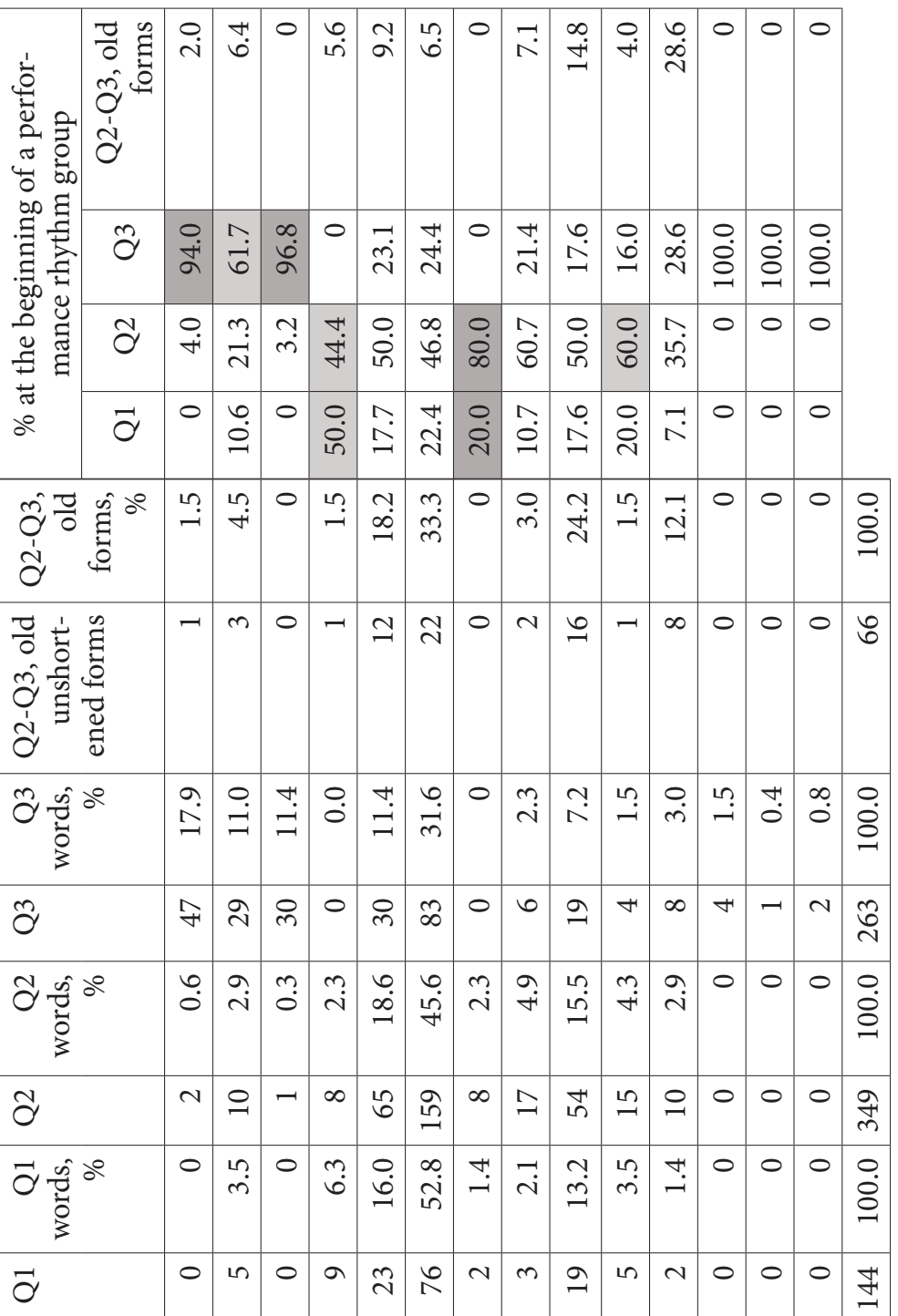

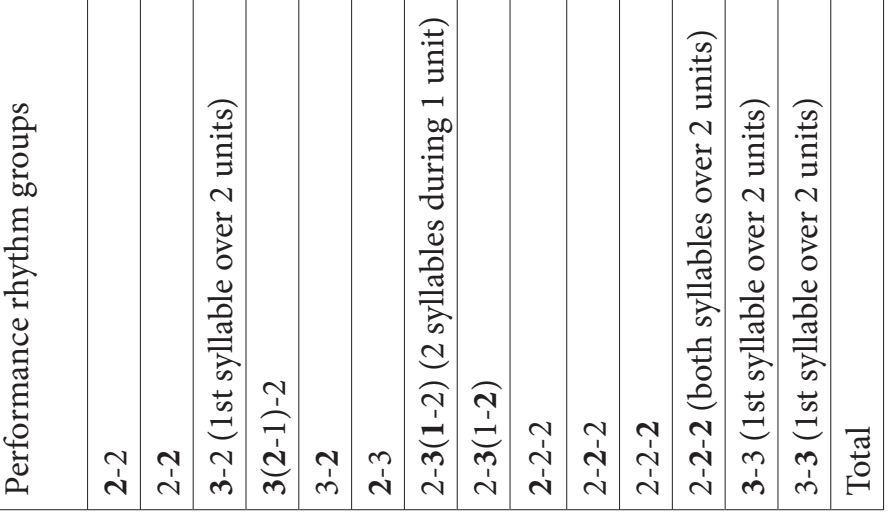


Disyllabic words can be found in all 2-unit performance rhythm groups as well as in 3-unit groups. In several structures, the choice of words depends on their quantity:

The first 2-unit group of the 2-2 structure consists, as a rule, of Q3 words in 47 out of 50 cases (the most frequent line is ol-go / nõa-ló 'on the shoulders'). A disyllabic word is often - in two-thirds of cases - in the third degree of quantity also in the second performance rhythm group of 2-2 structure.

In the first 3-unit group of the 3-2 structure, the Q3 disyllabic words occur only in a lengthened form ( $\boldsymbol{k} \boldsymbol{u}-\boldsymbol{u}-\mathbf{p a}$ / min-nä 'to go to the cave'), the Q3 initial syllable is never sung over a single metric unit. The Q1 and Q2 disyllabic words form in this structure a 3-unit group with a monosyllabic word (ai-a $\mathrm{mul} /$ a-sõld 'to bustle around').

A comparison of the two lament genres reveals that there are two alternative ways to place disyllabic Q3 words: in bridal laments, the second half-line beginning with a disyllabic Q3 word is sung shorter, with the performance rhythm structure 2-2; in death laments, the initial syllables of Q3 disyllabic words are divided between two metric units to form the 3-2 structure.

When discussing the abundance of disyllabic Q3 words in 2-2 as well as 3-2 performance rhythm structures and these structures as alternative ways to place disyllabic Q3 words, we should remember the assertion of Vaike Sarv that the disyllabic first verse foot/stress group in bridal laments is performed as extended by the lead singer (see footnote 16). Still, the singers perceive the 2-2 structure as different from the 3-2-structure - in bridal laments, a clearly differentiating melody variant is always used when singing the 2-2 structure (see Example 3b). In death laments, melodic variation does not differentiate between the 2-2- and 3-2-structures.

Also, in the 2-3 structure, disyllabic words take part in forming 3-unit performance rhythm groups. Disyllabic Q3 words never occur at the beginning of the final 3-unit group. Only disyllabic Q1 or Q2 words, sung quickly, during the first unit of the 3-unit group (ol-la / [u-mah] ma-jah 'to be in one's own house') can be found in this position. Disyllabic Q1, Q2 as well as Q3 words begin from the second unit of a 3-unit performance rhythm group. The placement of mono- and disyllabic words in the 3-unit group of the 2-3 structure indicates a boundary separating the first and final two units. Neither mono- nor disyllabic words cross that border (but a trisyllabic word can fill a whole group).

The 2-2-2 structure, used as an alternative to the structure 2-3 and occurring only in death laments, contains disyllabic words in every performance rhythm group. In the intermediary group (2-2-2), the number of disyllabic Q1 and Q2 words is slightly larger compared to other rhythm groups of the given structure 
( $80 \%$ in total). This may not be coincidental because these two syllables are placed into one musical unit in the alternative 2-3 structure, particularly in the bridal laments, and Q1 and Q2 words are suitable for this purpose.

\section{Trisyllabic words}

As in the first half-line, trisyllabic words are also placed in the second half-line according to specific rules, and here, too, Q1 and Q2 words stand out from Q3 words (Table 9).

Trisyllabic Q1 and Q2 words form the 3-unit performance rhythm group in the 3-2 structure (e.g., ko-go-ni / hös-te 'very well'). Trisyllabic Q3 words in this position are an exception.

The vast majority of trisyllabic Q3 words as well as old (partially) unshortened forms belong to the 3-unit performance rhythm group of the structure 2-3 (e.g., ko-do / kal-du-da; nõ-sõ / nõud-ma-he 'to go home'; 'I will demand [you to tell me]').

As an alternative, in death laments some trisyllabic words belong to the second and third group of the 2-2-2 structure. In that case, the trisyllabic word is placed in the same way as in the first half-line. If it is a Q3 word, its initial syllable comprises two musical metrical units (6 lines, e.g., koo-lu / ko-(o) $\boldsymbol{h}$-/to-he 'bring Death to trial'). If it is a Q1 or a Q2 word, the last syllable is divided between two musical metrical units (5 lines, e.g., vak-ka/va-la-/ma(a) 'to prepare the bridal chest'). ${ }^{23}$

Next to the more frequent cases of placing trisyllabic words, more important special cases should be mentioned:

1) The 3-unit performance rhythm group of the structure 2-3 is formed by a trisyllabic Q1 or Q2 word on four occasions (in that case, there is no secondary stress on the second unit, as is characteristic of other cases of the 2-3 musical structure).

2) Both the 3-3 structure and the 33 syllable structure occur in the second half-line on only three occasions. The 3-3 structure is used only in death laments (here, unlike in bridal laments, the half-lines have 6 musical units). The 3-3 structure is formed from the 23 or 32 syllable structures, lengthening the disyllabic Q3 word (ma-ri-ja / mä-e-le 'on the hill of berries'). At the same time, three 33 syllable structures, all found in bridal laments, are sung with

\footnotetext{
23 Such forms occur only in a single death lament, in which the short form of the final word is used similarly to solo laments (Olga Proskin, Marva Lõhmus, Meldova v., collected by Paul Hagu 1974, EKRK, Fon. 87 (11), the longer form in the example given here would be valamahe). As the line ends with a fermata-like extending, these musical structures could be interpreted also as 2-3 structures. Here they are interpreted as 2-2-2-structures because they are situated between successive lines with the clear 2-2-2-structure.
} 


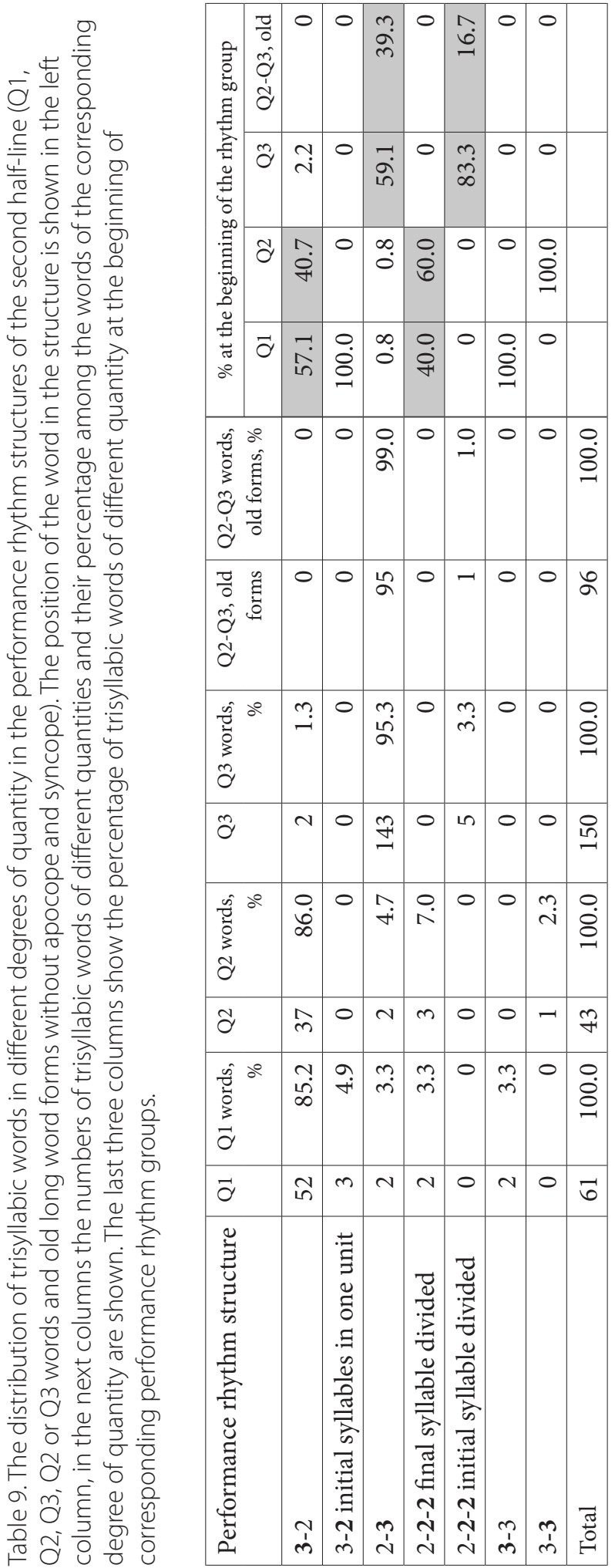


the 3-2 performance rhythm structure: two initial syllables of the last trisyllabic word, which in all cases is a Q1 word, are compressed on one metric unit (u-ma-lõ / [o-ho]-ló 'into my own misery')

\section{Quadrisyllabic words}

Of quadrisyllabic words, almost all Q3 words are in the 2-2-structure (8 in total; there is also a Q2 word in this position). One Q3 word forms the 3-2-structure by dividing the initial syllable into two musical metrical units. All other quadrisyllabic words (excluding a few exceptions) are Q1-Q2 words and belong either to the 2-3 (82 in total: 74 in bridal laments, 8 in death laments) or the 2-2-2 (69, all in death laments) musical structures. Again, the figures show that there are alternatives - a quadrisyllabic word, sung mostly syllabically in death lament, is sung faster in bridal laments, with two initial syllables sung during the first unit of a performance rhythm group (in death

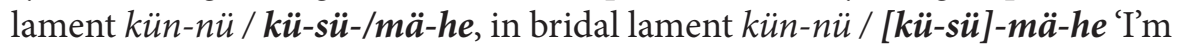
going to ask you'). In a faster performance (the 2-3 structure), the short vowel of the first Q1 word is silent (küsümähe > ksümähe; mar'akõnõ > mrakõnõ). There are more quadrisyllabic words in the second half-line, including all Q3 words and most of the Q1 words. In the case of the Q2 words, the difference from first half-line is smaller.

\section{Pentasyllabic words}

Pentasyllabic words are always either Q1 (32) or Q2 (5) words and form

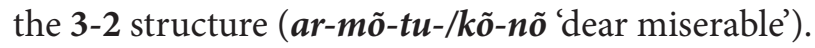

\section{The length of syllables positioned on the first units of performance rhythm groups and a summary of the analysis results}

In laments, words are organized in a line according to the same principles than in the previously analyzed corpora of Seto runosongs (Oras, Iva 2017).

1. As a rule, one syllable corresponds to one musical metrical unit.

2. The 3-unit group of the 2-3 structure in the second half-line is remarkably different from other groups:

a) a Q3 syllable (a monosyllabic word or the first syllable of a trisyllabic word $)^{24}$ or the first two syllables of a disyllabic or quadrisyllabic Q1 or Q2 word are sung over the first metric unit;

b) the first and the second unit are separated - the second unit always carries the secondary stress of a tri- or quadrisyllabic word or the stress of a disyllabic word.

\footnotetext{
24 The majority of trisyllabic Q3 words can be found in the 2-3 structure.
} 
(There are 4 lines where the 3-unit group is formed by a trisyllabic Q1 or Q2 word without a secondary stress on the second syllable.)

3. In other performance rhythm structures a monosyllabic Q3 word or the first syllable of a multisyllabic Q3 word is very often sung over two musical metrical units:

a) the first syllable of a trisyllabic Q3 word is generally (in 18 cases out of $20)^{25}$ divided over two metric units;

b) the first syllable of a disyllabic Q3 word is divided over two metric units in 3-unit groups (primarily in the 3-2 structure in the second half-line; in 2-unit groups it is sung over a single unit);

c) a monosyllabic Q3 word is often divided over two metric units.

4. Placing monosyllabic words in the end unit of both the first and the second half-line (except for the word-final negation particle) is avoided.

Lines with a similar linguistic syllable structure are sung in shortened form in bridal laments and in longer form in death laments, using a smaller or larger number of musical metrical units, respectively.

1. In the second half-line, the structures consisting of 4 syllables $(22,4$, also 21) are performed with the performance rhythm structure 2-2 in bridal laments and mainly 3-2 in death laments; at that, the first group begins with a Q3 word in 92\% of the cases;

2. In the second half-line, the structures consisting of 5 and 6 syllables (23, $212,222,24$, etc.) are always sung with a shorter, 2-3 performance rhythm structure in bridal laments; in death laments also the longer, 2-2-2 structure is used. In the 6-syllabic half-lines of death laments, performed with the 2-2-2 structure, the third syllable (the first syllable of a di- or quadrisyllabic word) is usually in Q1 or Q2 (in 89 out of 93 cases) - the syllable structure as if reflects the possibility to perform it with the shortened 2-3 structure.

Also, it must be remembered that in bridal lament, the end (the two final syllables) of the choral part is always sung faster. Therefore, the musical line end structures in bridal laments, analysed here, were identified on the basis of the singers' line (the choir joins the lead singer usually on the third note from the end of line).

Even though the length of performance rhythm structures that are used to perform linguistically similar lines varies in the second half-line (the possible alternatives are 2-2 3-2 and 2-3 2-2-2), the isochronic tendency can still be detected owing to the quantity degree composition: word degrees and the

25 In the two remaining cases, the first syllable of a trisyllabic Q3 word is sung over one musical metrical unit in the 3-2 structure. 
number of musical metrical units as if balance each other. If the number of metric units is smaller, the word-initial Q3 syllables are usually sung over a single metric unit, whereas in structures of a larger number of metric units, the word-initial Q3 syllables are divided over two metric units (see Table 10).

1. In the shorter 2-2 and 3-2 structures of the second half-line of laments, the 2-2 structure generally starts with a Q3 syllable and the 3-2 structure with a Q1 or Q2 syllable (also, with a part of a Q3 syllable sung over two musical metrical units). The second rhythm group of either structure contains words of all quantities, but the 2-2 structure contains a significant number of first Q3 syllables. Here, the isochronic tendency in the 2-2 and 3-2 structures is revealed - the preferred combination in the 2-2 structure is long- $x / \boldsymbol{x}$ (long)- $x$ and in the 3-2 structure short- $x-x / x-x$.

2. In the longer 2-3 and 2-2-2 structures of the second half-line of laments, the end part varies. In the 3-unit group of the 2-3 structure, the first unit is an overlong syllable (the first syllable of a Q3 word or a monosyllabic word) or two short syllables (a disyllabic Q1 or Q2 word or the first syllables of a quadrisyllabic word) have been compressed on this unit. In the second group of the 2-2-2 structure, the first syllable of the first unit is fairly often a Q1 or Q2 syllable (also, a part of a Q3 syllable sung over two musical metrical units). The isochronic tendency can also be seen in the 2-3 and 2-2-2 structures: the 2-3 structure is characterized by the "heavy" beginning of the 3-unit rhythm group $-x-x /$ long $\sim[x \boldsymbol{x}]-x-x$, and the length of a 6 -unit structure is as if balanced by the use of shorter first syllables $-x-x /$ short $-x-x / x-x$.

Table 10. The quantity degree of stressed syllables of multisyllabic words in the initial units of performance rhythm groups in the second half-line of choral laments.

\begin{tabular}{|c|c|c|c|c|c|c|}
\hline \multirow{2}{*}{$\begin{array}{l}\text { Performance } \\
\text { rhythm structure }\end{array}$} & \multicolumn{6}{|c|}{ Musical metrical units } \\
\hline & 1 st & 2nd & 3rd & 4th & 5 th & 6th \\
\hline $2-2$ & \multicolumn{2}{|c|}{ Q1-Q2 5/ Q3 55} & \multicolumn{2}{|c|}{ Q1-Q2 10/ Q3 29} & & \\
\hline $3-2$ & \multicolumn{3}{|c|}{ Q1-Q2 176/ Q3 2} & \multicolumn{2}{|c|}{ Q1-Q2 94/ Q3 32} & \\
\hline $2-3$ & \multicolumn{2}{|c|}{ Q1-Q2 244/ Q3 82} & \multicolumn{3}{|c|}{ Q1-Q2 0/ Q3 161} & \\
\hline $2-3 *$ & \multicolumn{2}{|c|}{ Q1-Q2 3/ Q3 1} & \multicolumn{3}{|c|}{ Q1-Q2 4/ Q3 0} & \\
\hline $2-2-2$ & \multicolumn{2}{|c|}{ Q1-Q2 79/ Q3 20} & Q1-C & 9/ Q3 4 & \multicolumn{2}{|c|}{ Q1-Q2 15/ Q3 8} \\
\hline $3-3$ & \multicolumn{3}{|c|}{ Q1-Q2 3/ Q3 0} & \multicolumn{3}{|c|}{ Q1-Q2 3/ Q3 0} \\
\hline
\end{tabular}

In this Table, the first syllable of Q3 words, or monosyllabic Q3 words, sung as extended over two metric units, has been regarded as two "song syllables" - the first component of a divided Q3 syllable is regarded as a separate "song syllable" of short 
quantity degree and is categorized as a Q1-Q2 syllable. In the same performance rhythm structure, the number of words that start from different metrical units does not coincide mainly because a large number of old word forms had to be excluded, the quantity degree of which cannot be determined in the contemporary threedegree system (see below).

The slash separates the number of metric units beginning with Q1-Q2 syllables or Q3 syllables. These metric units which show a clear majority of either shorter (Q1Q2) or third quantity degree are given in bold.

The structure ...-2-3*, marked with an asterisk, includes lines in which the last performance rhythm group is performed with a trisyllabic Q1 or Q2 word, whereas its first syllable fills one metric unit and the second unit of the group has no secondary stress.

The Table does not include (a) the old forms without apocope and syncope, in which the initial syllable is not divided; (b) words that may be either Q2 or Q3 words; (c) the cases in which the first unit of a rhythm group has two syllables (the first syllables of a quadrisyllabic Q1 or Q2 word or a disyllabic Q1 or Q2 word); (d) the cases in which the rhythm group begins with a secondary stress of a longer word. The most numerous of these are the following: in the 2-3 structure, the first unit of a 3-unit group includes old, longer forms in 93 cases, and Q2 or Q3 words in this position in 2 cases; in the 3-unit group of the 2-3 structure, two syllables are sung over the first unit in 92 cases; in the 2-2-2 structure, the first unit of the first group includes old, longer forms in 15 cases etc.

\section{Comparison of the metrics of laments and runosongs}

\section{Principles of comparison and comparative data}

One of the research objectives of this paper was to inquire how to describe the metrics of Seto singing tradition as a whole and to analyze the reciprocal interrelation of its subcategories. More specifically, the inquiry concerns the relations of Seto lament and the rest of the runosong tradition. While the poetic texture of laments seems to resemble that of runosongs, it is not entirely clear whether Seto lament, in terms of its poetic composition, should be approached as a subcategory of runosong tradition or an entirely separate song category. It is also not clear whether laments and runosongs were originally two branches of the same poetic tradition or are they of different origin. To explore these issues and weigh the alternative possibilities, we will compare the results of the metric analysis of three song groups: the choral laments discussed in this paper and the songs with the feast melody and refrain songs analyzed in our previous research articles (Oras, Iva 2017; Oras 2019; Oras, Sarv 2021).

For the purpose of a more successful comparison of the texts of different song groups, it is practical to juxtapose the part of the line that comes after 
structural or occasional additional syllables and/or repetitive words. In Seto runosong, the first two syllables of a line are often separated from the rest of the line by a repetition or an additional syllable - this has also been the case in the songs with the feast melody and (the lead singer's part of) refrain songs studied before. In the case of the "extended beginning" of a line (in the longer version of the harvest song and in laments), the first four syllables are separated by an additional syllable (see Example 4). While the structure of the initial part of the line varies across the song categories, the structure of the ending part, following the additional syllable (with addressing word) and/or the repetition, is easily comparable in different song categories.

\section{Songs with feast melody:}

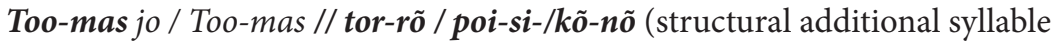
and repetition)

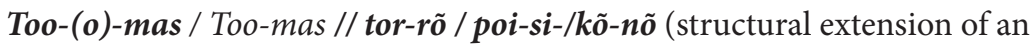
initial syllable and repetition)

\section{Songs with a refrain:}

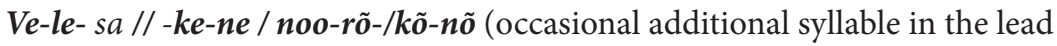
singer's part of the wedding song)

Kä̈i-ge ti, // kul-l'a / $\boldsymbol{k} \ddot{a}-\boldsymbol{e}$-/ke-se (structural additional syllable in the shorter version of the harvest song)

No-o,/ kä̈̈-ge ti, // kul-l'a / $\boldsymbol{k a ̈}-\boldsymbol{e}$-/ke-se (structural “extended” beginning and an additional syllable in the longer version of the harvest song)

\section{Laments:}

Sõb-ra-/kõ-nõ,/ sõb-ra-/kõ-nõ,/ u-mast/ vee-me mi // ko-tost / ko-go-/nis-ta (addressing formula, structural "extended" beginning and an additional syllable in the choral part of the death lament)

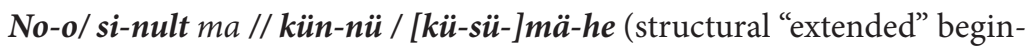
ning and an additional syllable in the lead singer's part of the bridal lament)

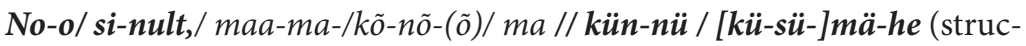
tural "extended" beginning, addressing formula and an additional syllable in the choral part of the bridal lament)

\section{Example 4. (Hypothetical) main lines in the three compared song groups. The} ending part is separated by a double slash. The additional syllables and addressing formulas are underlined; the main line is in bold; the beginnings of lines which have been "extended" (four syllables/musical metrical units instead of two) are in the lighter script. Translations: 'Toomas, a nice youngster'; 'Dear brother, dear young man'; '(Well,) move my dear hands'; 'Dear friend, dear friend, we are taking you from your home'; 'Now, (dear mother,) I'm going to ask you'. 
Table 11. The performance rhythm structures of the ending part of line in Seto runosongs and choral laments.

\begin{tabular}{|c|c|c|c|c|}
\hline $\begin{array}{l}\text { Performance } \\
\text { rhythm structure }\end{array}$ & $\begin{array}{r}\text { Songs with the } \\
\text { feast melody }\end{array}$ & Refrain songs & $\begin{array}{r}\text { Bridal } \\
\text { laments }\end{array}$ & $\begin{array}{r}\text { Choral death } \\
\text { laments }\end{array}$ \\
\hline$\ldots-2-2-2$ & $480(83.2 \%)$ & $671(58.4 \%)$ & - & $116(38.5 \%)$ \\
\hline$\ldots-3-3$ & $97(16.8 \%)$ & $146(12.7 \%)$ & - & $3(1.0 \%)$ \\
\hline$\ldots-3-2$ & - & $35(3.0 \%)$ & $89(20.5 \%)$ & $90(29.9 \%)$ \\
\hline$\ldots-2-3$ & - & $283(24.6 \%)$ & $267(61.4 \%)$ & $81(26.9 \%)$ \\
\hline$\ldots-2-3^{*}$ & - & $11(1.0 \%)$ & $1(0.2 \%)$ & $3(1.0 \%)$ \\
\hline$\ldots-2-2$ & - & - & $52(12.0 \%)$ & $8(2.7 \%)$ \\
\hline Other ${ }^{* *}$ & - & $4(0.3 \%)$ & $26(6.0 \%)$ & - \\
\hline Total no. of lines & $577(100 \%)$ & $1150(100 \%)$ & $435(100 \%)$ & $301(100 \%)$ \\
\hline
\end{tabular}

The performance rhythm groups are determined on the basis of lexical stress (or secondary stress, see Material and methods). In laments and refrain songs, the ...-2-3 structure represents the lines in which the method of shortening has been applied in the performance. The ...2-3* structure marked with an asterisk includes lines that do not correspond to the shortening method (the lines in which the final three-unit group begins with a trisyllabic Q1 or Q2 word and the second unit of the group has no secondary stress). Other ${ }^{* *}$ indicates exceptions: a) in the lines of refrain songs, in which the three-unit group at the beginning of a line features a trisyllabic word instead of a structure containing a disyllabic word and an additional syllable; b) in bridal laments these are half-lines with addressing formulas, in which the additional syllable is followed only by the word kaligo, which is sung during three musical metrical units.

Table 11 shows the results of the comparison of the lines' ending parts in three song groups on the level of performance rhythm. In order to delve deeper from the performance rhythm structures to the level of verse structure, the diversity of the structures may be evened out further. The verse structure level could serve as an interpretive middle ground between the linguistic and musical structural level (cf. Table 5) - the verse structure is identified here based on musical performance, although without taking into account the most variable part of the performance. Two regular occasions where a verse structure is interpreted in two different ways in musical performance can be pointed out. 
1) As already mentioned, in refrain songs, the ending parts of the lines of a typical $2+2+2+2$ verse $^{26}$ are performed not only over three $(\ldots-2-2-2)$ but sometimes also over two performance rhythm groups (...-2-3, whereas the final group characteristically has the (secondary) stress on the second unit, see Example 5). In our previous studies, we have suggested that the latter case can be interpreted as the $2+2+2+2$ verse structure shortened in musical performance - as the ...-2-3 were the surface-level or performance structure. Since in choral laments the lines with the ...-2-3 performance structure have the exact same linguistic features, we could similarly interpret these lines as the musically shortened variants of the $2+2+2+2$ verse structure. These "shortened" lines are most commonly found in bridal laments, characterized by an accelerated ending (in death laments the same syllable structures have been performed also as ...-2-2-2 performance structures).

\section{Linguistic structure:}

... ko-do kot-ta-lõ 2 (Q1), 3 (Q3, secondary stress on the 2nd syllable)

... kul-la ko-do tul-la 2 (Q2), 2 (Q1), 2 (Q2)

Verse structure:

$2+2+2+2$

Performance rhythm structure:

Feast melody

// ko-do/ ko-(o)t-/ta-lõ

// kul-la/ ko-do/ tul-la

\section{Refrain songs, death laments}

// ko-do/ ko-(o)t-/ta-lõ OR // ko-do/ kot-ta-lõ (shortening in performance)

...-2-2-2 OR ...-2-3

// kul-la/ ko-do/ tul-la OR // kul-la/ [ko-do] tul-la (shortening in performance) ...-2-2-2 OR ...-2-3

\section{Bridal laments}

// ko-do/ kot-ta-lõ (shortening in performance)

// kul-la/ [ko-do] tul-la (shortening in performance)

Example 5 . Realization of two typical linguistic structures of the ending part of $2+2+2+2$ verse in different song groups. In fact, the same lines are not used verbatim in all the song categories; in some cases, the comparison is based on lines with an analogous linguistic structure. Translation: 'to place of home'; '[you] dear one [cannot] come home'.

26 Here and in the following verse structure formulas, the "extended" beginning is reduced to a 2-unit stress group. 
2) If the lines of the $\ldots-2-3$ musical structure can be interpreted as the performance variant of the $2+2+2+2$ verse structure, then it is possible to interpret the ...-2-2 performance structure of choral (mostly bridal) laments according to the same principles. The latter would then be a performance variant of the $2+3+2$ verse structure, a surface-level structure formed in a musical performance by means of shortening (Example 6). Interpreting it as such is further supported by the fact that in the ...-2-2 structure, the first syllable is in most cases a Q3 syllable (which would enable the alternative ...-3-2 performance). The two structures of performance are not clearly distinguishable - as in the case of ...-2-2-2 and $\ldots-2-3$ structures, it is sometimes difficult to determine auditorily whether the $\ldots-2-2$ or the ...-3-2 performance structure has been used. ${ }^{27}$

\section{Linguistic structure}

... tüh-jä tar-rõ 2 (Q3), 2 (Q2)

... vae-sõ-kõ-nõ 4 (Q3)

\section{Verse structure}

$2+3+2$

\section{Performance rhythm structure}

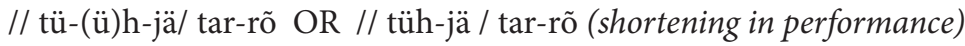
...-3-2 OR ...-2-2

// va-e-sõ-/kõ-nõ OR // vae-sõ-/kõ-nõ (shortening in performance) ...-3-2 OR ...-2-2

Example 6. Linguistic and performance structures of tetrasyllabic line endings interpreted as alternative performance variants of the same $2+3+2$ verse structure. Translation: 'of empty room'; 'poor little thing'.

27 This applies to death laments because in bridal laments the structures can be distinguished by the pitch structure. However, according to Vaike Sarv, the boundary is somewhat blurred also in bridal laments because in performance, the four-syllabic second half-line is actually sung using ...-3-2 performance rhythm groups, even though Sarv's transcriptions do not really confirm her claim (see above p. 70). The interpretation of the ...-2-2 musical structure as shortened in performance can be objected to. If we compared the two structures, which are here interpreted as shortened in performance (...-2-3 and ...-2-2), then the principle of positioning the initial syllable of a Q3 word is exceptional in the first case and quite common in the second case. The Q3 initial syllable of trisyllabic words is sung during one metric unit only in the ...-2-3 structure - in other positions of a musical line, the first syllable of a trisyllabic Q3 word is usually divided over two units. The two initial syllables of Q1 or Q2 words are rarely compressed to one unit, as they are in the ...-2-3 structure as well. In the ...2-2 structure, the initial syllable of a disyllabic Q3 word is sung during one metric unit. Unlike a trisyllabic word, singing the initial syllable of a disyllabic Q3 word during one metric unit is quite common also in other positions of a musical line. 
If the described performance rhythm structures ...-2-3 and ...-2-2 are interpreted as shortened in performance and the corresponding verse structures are identified as the $2+2+2+2$ and $2+3+2$ structures (as hypothetical deep-level verse structures), the summarizing table (Table 12) is far more homogeneous than the previous table, which covered all the performance rhythm structures (Table 11).

Table 12. Hypothetical deep-level verse structures (combinations of stress groups) in Seto runosongs and choral laments. The "extended" beginnings of laments and the longer version of the harvest song are reduced to a 2-unit first stress group.

\begin{tabular}{|r|r|r|r|}
\hline Verse structure & Songs with the feast melody & Refrain songs & Choral laments \\
\hline $2+2+2+2$ & $480(83.2 \%)$ & $954(83.0 \%)$ & $464(63.0 \%)$ \\
\hline $2+3+3$ & $97(16.8 \%)$ & $146(12.7 \%)$ & $3(0.4 \%)$ \\
\hline $2+3+2$ & - & $35(3.0 \%)$ & $239(32.5 \%)$ \\
\hline $2+2+3$ & - & $11(1.0 \%)$ & $4(0.5 \%)$ \\
\hline Total no. of lines & $577(100 \%)$ & $1146(99.7 \%)^{\star}$ & $710(96.5 \%)^{*}$ \\
\hline
\end{tabular}

* Exceptions to the structures of refrain songs and bridal laments are not included in the table (see Table 11).

Similarities and differences in metric structures of Seto runosongs and laments

The comparison of Seto song groups on the level of the performance (see Table 11 ) as well as of the verse structures (see Table 12) clearly reveals significant overlapping in the line structures of both runosong groups and laments. In addition, the similarities include other common principles of structure:

* Syllabic line;

* The separateness of the (extended) $1^{\text {st }}$ "verse foot";

* The same general positioning principles of initial syllables of different quantity degrees - i.e. which syllables are divided over two musical metrical units and which syllables are condensed in a way that two syllables are sung for the duration of a single metric unit (Tables 7-9; Oras, Iva 2017: 182-184);

* The same principles of the choice of words by quantity degree in certain positions of a line (Table 10; Oras, Sarv 2021, Tables 2, 3 - data on the quantity degrees of songs with the feast melody and refrain songs is available only on structures consisting of 3-unit performance rhythm groups). 
There are, however, also clear divergences in the use of different structures in different song groups in Seto tradition. The majority of Seto runosongs, here represented by songs with the feast melody, have lines of stable length. In these songs, the most common verse structure is the main runosong verse structure $2+2+2+2$; regarding the verse structures of 3 -unit stress groups (the so-called broken verse structures of runosong, Sarv 2019: 106-107), only 2+3+3 structures can be found. The diversity and complexity of rhythm are caused by repetitions and additional syllables.

Between the main body of runosongs and laments, there is a group of songs with refrain (these constitute a tiny group of song types; at the same time, the wedding and harvesting songs were an obligatory part of central community rituals). The share of the two most common verse structures in refrain songs is very similar to that in other runosongs with stable line length. However, in its representation of two shorter, 7-position verse structures, as well as in the use of the method of shortening in performance, this group as if bridges other runosongs and choral laments.

The choral laments differ the most from the main body of Seto runosongs. The beginning part of a lament line is extended (still, this structure occurs in one version of refrain song) and in the singing performance, the length of a line's ending part varies from 4 (in a definite addressing formula 3) to 6 musical units. The $2+2+2+2$ verse structure is found in laments less than in runosongs and the $2+3+3$ structure is almost missing. However, the $2+3+2$ structure, which is missing in the songs with stable line length and is relatively rare in refrain songs, has an important place in laments.

In the case of laments, attention must be drawn to the differences between the share of verse structures and actual sound impression. In lament rhythmics, the dominant (and in bridal laments the only) musical ending structure is that of 5 metric units. Herewith, the musical accent is on the penultimate note, so that the musical grouping perceived by the listener is $3+2$ (see Examples 1 and 2 ). From the perspective of the poetic meter different metrical structures are mostly sung with the same harmonic sequence - among them the $2+2+2+2$ structure with the method of shortening (performance rhythm ...-2-3), and rare $2+2+3$ structures. In the last cases the performance rhythm structure is $\ldots-2-3$ and musical harmonic structure is ...3+2. Thus a conflict of word and musical stresses arises, that is not characteristic of the basic structure of the line in Seto songs. By the way, the same conflict is typical also to the performance of the $2+3+3$ structures (so called broken line structures) in the songs with the lines of stable length.

Considering the weight of the 5-unit musical harmonic structure, we have to admit that, in a sense, highlighting the verse structure level overshadows 
the central role of it in the second half-line of laments. At the same time, we cannot forget that the structure of six isochronic musical metrical units is quite usual ( $38.5 \%$ of lines) in choral death laments that share the same structure with another most prominent (and probably also primary) kind of laments - solo death laments. Discerning the verse structure level also helps to emphasize the importance (and primacy?) of the $2+3+2$ structure - it cannot be a coincidence that the ending musical harmonic contour is "appropriate" to the $2+3+2$ structure, owing to the musical functions of the scale steps and patterns of the alternation of harmonic complexes in one-three-semitone scale (footnote 17, Pärtlas 2001, 2006b, 2018).

\section{Comparison with other Finnic song regions, possible patterns of development}

The obvious similarities and differences in the metric organization of the three song groups raise the question of their cause. The answer should be sought in the general development history of Seto runosong and lament, which is related to the development and changing of runosong in other areas and may also indicate influences outside the runosong tradition.

The most recent theories suggest that some particular features of South Estonian language and culture are connected to the differentiation of coastal and inland cultures already before the Late Proto-Finnic, which developed in the northern Estonia along with the rich archaeological culture as a result of the encounter of Finnic and Palaeo-Germanic population, and later spread and divided further into different Finnic languages (Lang 2018: 224, 242-265, cf. also Kallio 2014, 2015). Late Proto-Finnic has been considered a language stage suitable for the emergence of syllabic runosong meter (Korhonen 1994), that possibly developed under the influence of early Germanic culture (Frog 2019). These theories imply that runosong might have been evolved concurrently with the major Proto-Germanic contribution to the Finnic language in the northern Estonian region, and later migrated from the north to South Estonia (cf. Sarv 2019; Frog 2019). On the basis of archaeological material, the influences of the Late Proto-Finnic culture reached the territory of Southeast Estonia from the northern as well as from the southwestern direction (Lang 2018: 221-223). An important channel of economic and cultural contacts was also the waterway from the territory of eastern Setomaa via Lakes Pskov and Peipus to the Gulf of Finland (Valk 2011).

The Finnic peoples of Southeast Estonia and northern Latvia were closely connected with the Baltic peoples and the Western Ural branch of Finno-Ugric 
peoples who dwelled east of the territory of Setomaa. Contacts with the east, as far as to the Mordovian peoples, can be also traced throughout the 1st millennium CE (Lang 2018: 191, 243-244; Laul 1997; 2001: 182-185, 261). According to archeological, linguistic and also ethnological and folkloristic data, most of these southern and eastern influences did not reach North and West Estonia - already in the 1st millennium BCE but more remarkably in the period following the Roman Iron Age (1st-5th century CE). In the second half of the 1st millennium, a cultural border between the territory of current Setomaa and other parts of Southeast Estonia can be detected. In the last decades of the 1st millennium, the Slavicization of the territories east of Setomaa began and the Slavic culture influenced also the orthodox Setomaa in subsequent centuries. In addition, there were also some differences between different parts of Setomaa which deepened in the 11th-14th centuries (Lang 2018: 244-245, Valk 2011: 36-37).

Ingrid Rüütel $(1990,1996)$ has pointed out different musical as well as other features in Seto singing culture that are connected to the different cultural regions mentioned above - many of these are missing from the runosong of North and West Estonia and some also from other parts of South(east) Estonia. Žanna Pärtlas has considered the rare Seto musical scale system and the type of polyphonic texture as the key to the origin of Seto song culture, since these musical features are missing from the neighboring areas of Seto and seem to be very old. She has pointed out the parallel phenomena on the previous FinnoUgric territories in South Russia and, to a degree, also in Mordovia. Next to the common features of earlier origin, some of the similar stylistic elements do not appear to be so ancient and could be explained by the long cultural contacts with the eastern Finno-Ugric tribes, which probably lasted until the beginning of the 2nd millennium CE (Pärtlas 2005, 2006a).

It is possible to point out some specific features also in the meter of Seto songs and laments that are not found in the metrical structure of the runosongs of other regions.

1) One key feature of the Seto runosong meter seems to be that the first "verse foot" is "separated" in many musical structures: in Seto songs, the 2-unit first stress group of a line is very often expanded by an additional syllable (or sometimes by doubling the duration of the first syllable), forming a 3-unit performance rhythm group). Such 3-unit structures are difficult to adapt to the broken runosong line structures beginning with the 3-unit stress group $(3+2+3$ and $3+3+2)-$ two kinds of initial 3 -unit groups get "mixed up" with 
each other. This can be considered a reason why the main body of Seto runosongs include only the broken verse structure with a 2 -unit beginning, $2+3+3$.

The structural 3-unit beginning is quite a frequently found feature of characteristic Seto "long tunes", in which additional syllables, stretching of syllables (over two notes/musical rhythmic units) and repetitions are used to match the octosyllabic verse to the melody. Such melodies were probably not originally connected to the runosong verse. Repetitions and additional syllables are also found elsewhere in Southeast Estonia and Ingria, but the 3-unit initial group (where an additional syllable is added to the first verse foot) seems to be characteristic precisely of Seto songs. Ingrid Rüütel has pointed out some parallels of the rhythmic structure of longer Seto melodies with the songs from southern and eastern areas that have had cultural contacts with the territory of Setomaa in prehistoric times - Lithuania, western Russia, Belarus, Mordovia (Rüütel 1990: 105-106). The origin of Seto long melodies, as well as the use of the initial 3-unit rhythm group, is difficult to be determined more precisely. As said in the introduction, it is not even clear whether the runosong structure was adopted in Setomaa together with the 8-note melodies corresponding to octosyllabic lines or the melodies longer than 8 notes were already known there before the poetic structure of runosong was adopted. Thus, the 3-unit initial structure is an innovation from the point of view of runosong style, but it is hard to guess the time of its emergence - if the structure has been in use in an earlier poetic culture which later has adopted the poetic system of runosong, or has it developed as an innovation within the runosong culture, possibly under the impact of some other musical culture. The caesura after the (extended) first "foot" is a common feature of the structure of Seto laments and Seto runosongs and, together with other similar features, shows the close connection between them.

2) Another conspicuous peculiarity is the varying line length in refrain songs and laments. As explained before, it is a result of using 7-position verse structures on the one hand and the method of shortening in performance on the other.

The refrain songs also seem to be influenced by the 3-unit initial group principle having an occasional or structural additional syllable after the second syllable of the main line. Therefore, the broken verse structures of runosong with a 3-unit beginning do not match refrain songs either. Still, more different structures with 3-unit stress group(s) can be found in refrain songs than in the songs of stable line length and these structures represent 7-unit lines. We can imagine that the refrain enabled the more flexible length of the main line and this resulted in the emergence of the verse structures $2+2+3$ and $2+3+2$, 
which could be interpreted as the shorter versions of the common runosong structures $3+2+3$ and $3+3+2 .{ }^{28}$

Refrains are common in the South-Estonian tradition in general, but the first verse foot being "separated" and the varying line length are characteristic only of Seto refrain songs. Seto refrain songs must belong to quite an early tradition because they are related to old ritual song genres. Compared to the other Seto multipart songs, their melodies are closest to the melodies of the oldest musical layer of other South-Estonian regions. According to Ingrid Rüütel, the refrain tradition originated in the Baltic-Slavic cultural unity and formed in the local tradition as a symbiosis of the ancient Finnic and Baltic cultures in approximately 2nd-4th centuries CE (Rüütel 1990: 120; 1996, cf. Laul 2001: 220). Rüütel's timing is connected to earlier ideas about the development of the Finnic languages, she assumes that the earlier melodic layer (before the adapting of refrains in South-Estonia) formed already in later Bronze Age and earlier Iron Age. If to assume that Finnic tetrameter with the earlier melodies could not reach South Estonia earlier than 2nd century, then, by reference to the stages of historical development of melodies, outlined by Rüütel, it can be assumed that the refrains were adapted to runosong later. Still, it cannot be ruled out that the runosong style and the refrains were taken into use in South-Estonia relatively simultaneously.

As in refrain songs, the 7- and 8-position verse structures are also represented in choral laments. Also, the principle of the "separateness" of the (extended) beginning works in laments as well as in other song groups. Compared to refrain songs (and other song groups) on the level of verse structure the characteristic feature of laments is the prevalence of the $2+3+2$ structure. While searching for reasons for that difference, one must also look at the third specific feature of the Seto tradition at the level of musical performance - the method of shortening in performance.

3) The method of shortening in musical performance is a phenomenon common to Seto refrain songs and laments. Using the $2+3+2$ verse structure as well as the method of shortening in performing the $2+2+2+2$ structure, the ending part of the sung line (following the additional syllable) consists of 5 notes (isochronic musical metrical units; in laments, mostly in bridal laments, also lines of the $2+3+2$ structure are shortened and performed with 4 isochronic notes). The pattern of five notes occurs in more than one-fourths of refrain song lines and is very common in laments - especially in bridal laments

\footnotetext{
28 We may even assume that runosong as the original system is reflected in the prevalence of Q1 and Q2 in certain positions (marked in bold) of the verse structures $2+3+3,2+3+2$ and $2+2+3$ (the last one is represented by only a few lines).
} 
where use of the shortening method is required. Since in death laments the shortening is not used constantly but as an alternative to the 6-note ending, it seems to be possible that the 5-note ending structure has emerged as one of the alternative musical structures next to the 6-note ending. This assumption is also supported by the musical harmonic rhythm of death laments, where the last musical accent is on the penultimate note in both ...2-2-2 and ...2-3 structures - using performance rhythm ...2-3 as if one note/syllable position disappears: XXOOXX > XXOXX.

The development of shortening would be associated with the major wave of changes in the language that included the systematic loss of vowels in certain positions of words resulting in a decrease of the number of syllables in words and the emergence of the system of three quantity degrees (13th-17th century, Rätsep 1989). ${ }^{29}$ At the same time, we should not exclude the possibility that shortening was part of the performance style of laments (especially bridal laments) already before language contraction.

Another possible explanation for the prominence of the 5-unit pattern in laments is the specific function and performance of lament genre. It is possible that the use of structures different from the majority of Seto runosongs somehow correlates with the specific function of the genre that also promotes formal distinction from other songs. Furthermore, in bridal laments, we can speculate that there is a link between the method of shortening, accelerated performance of all line endings of the choral part, and the movements accompanying the singing - it may well be that the physically demanding constant bowing made the singers save their energy as much as possible (an additional

\footnotetext{
29 Language contraction is also connected with the emergence of three quantity degrees in the Estonian language. Apparently, after this turn, in Seto songs Q2 gradually came to be used in singing similarly to how Q1 had been used before, in the function of the short quantity degree - to convey the meaning more successfully, the contrast between Q2 and Q3 had to be highlighted. In a similar manner, the distinction between Q1-Q2 and Q3 is made intuitively in modern popular music (e.g., Oras 1999). In spoken language, the Q1 and Q2 words share common features as well: the similar fundamental frequency contour; no secondary stress on the second syllable; the vowel of the second syllable is half-long in Q1 and often also in Q2 words, but never in Q3 words (Asu et al. 2016: 142; Ross \& Lehiste 2001: 49).

In East-Estonian dialects, the contrasting length is still perceived as the main feature for distinguishing between Q2 and Q3, unlike in West Estonia, where the distinction is based more on the perception of differences in pitch contour (Lippus, Pajusalu 2009). No clear difference has been identified between the pronunciation of quantity degrees in East and West Estonia (on the Seto language see Parve 2003a: 44-45); however, in her dissertation on the quantity of South-Estonian dialects, Merike Parve argues that "South-Estonian pitch contour is generally more stable and more unified than that of North Estonians" (2003b: 96).
} 
possibility to save energy in bridal laments would then be the shortened performance of the $3+2$ ending part with 4 musical units).

Next to the genre-specific and language-historical impulses of formation of the metrical peculiarities of the laments, there is a possibility that the (formation and) development of the lament structure has been influenced by some foreign melody calling for a longer beginning part and a 5-unit ending part. For example, in Russian as well as in Mordovian tradition, the 3-syllabic ending formula is quite common - although in many cases this formula is not sung with isochronic notes (Efimenkova 1980: 34, Boyarkin 1988: 202-243). It is possible to see one indication of the independent development of laments in the rare occurrence of the $2+3+3$ structure, which is quite frequent in two runosong groups. If the pattern of a 5 -unit ending part initially developed in laments, we may speculate that the 7-position lines and the method of shortening could be transposed from laments to refrain songs.

The characteristic features of Seto runosongs and laments demonstrate them as genres metrically near to each other and specific compared to the metrical structure of runosong in other areas. Still, some of the specific traits of Seto metrical structures and their performance can be found in the SouthEast Estonian runosong in general (however, the songs of Vorrumaa need further examination in this aspect). Most conspicuous are the same general positioning principles of initial syllables of different quantity degrees that can be connected to the language changes in the first half of the 2th millennium and also to the (continuous) influences of Latvian tradition (e.g. Sarv 2011b). Another feature could be a greater variability in the (performance rhythm) structures of South-Eastern runosongs (e.g. Oras 2004), compared to the runosongs of the northern areas - it can be traced back to the times of adaption of runosong style, but it is certainly connected to the later historical developments as well.

When placing Seto laments in the background of Finnic lament tradition we can see conspicuous difference: laments of other Finnic peoples lack fixed meter and are performed solo, Seto lament tradition includes solo as well as choral laments that have basically the same metrical system which is quite close to the metrics of runosongs. The earlier Estonian researchers, referred above, have seen the emergence of choral laments as an innovation, which, however, took place a long time ago. Indeed, choral laments may have emerged as a fusion of an earlier solo lament tradition with ritual polyphonic choral singing in weddings. If there was an external impulse for the development of choral lamenting, it should probably have come from the east. Choral wedding laments exist in northern and Nord-West Russia (also in Pskov region) and there are a lot of other similarities in rituals as well as in music (Efimenkova 
1980: 24-25, Pashina 2005: 212-214). Still, as North-Russian lamenting tradition has been influenced by the Finno-Ugric substrate, it is hard to determine the direction and time of potential cultural impacts.

\section{Conclusion}

The subtradition of runosong that developed in the Seto region, in the border area of the Finnic singing tradition, is characterized by a unique archaic polyphony, melodies exceeding eight notes in length and a meter that conspicuously differs from that in other runosong areas. The Seto song metrics varies depending on the song category - different variants of meter are associated with melodies that differ in certain features of the musical structure. The most important musical feature related to the use of different variants of meter is the stable or varying length of lines within a song. Most Seto melodies are of stable length; in this paper, such tunes are represented by the so-called feast melody. Among the melodies of varying length are the group of refrain songs (harvest songs, wedding songs and a game song) and laments.

The purpose of current study was to find out the principles of the metrics of Seto laments and compare it to the metrics of Seto and other Finnic runosongs. To comparatively describe the linguistic structures, performance rhythm structures and poetic metrical structures - as a generalization based on linguistic and performance rhythm structures -, we found it practical to compare the more stable ending parts of the verse lines (starting from the second stress group or verse foot). In Seto songs, the ending part of the line (starting from the second stress group) is often separated from the initial stress group (consisting of two verse positions) by an additional element an additional syllable, musical extension of a syllable and/or repetition. (In laments and in a longer version of the harvest song with a refrain, the initial part separated by the additional syllable is four syllables/musical metrical units long and can be interpreted as the extension of an initial two-unit group.) Exclusion of the first stress group (verse foot) of the line and all the additional elements allows to compare the different song groups, whereas it is important to remember that the musical structure in the performance which determines the genre identity of the song can only be described together with structural additional elements.

Depending on the song category, the number of different verse structures in a line ranges from two (in songs of stable line length) to four (in refrain songs and laments of varying line length). The melodies of stable length include 
the $2+2+2+2$ structure and of the structures with three-unit stress groups (of broken line structures of runosong) only the $2+3+3$ structure. In refrain songs, the main structures are similar to those in songs of stable line length, but similarly to laments, refrain songs also include 7-position structures. The main difference between refrain songs and laments is their noticeably uneven share of different verse structures. In laments, the $2+2+2+2$ structure is less prevalent compared to other song groups and the $2+3+3$ structure is very rare. The most common lament structure with three-unit stress groups is the $2+3+2$ structure, and there is only a small share of this structure in refrain songs. A possible reason why only verse structures with a two-unit beginning (in one refrain song structure and in laments with an "extended", four-unit beginning) occur in all the analyzed song categories is the "separated" first stress group (verse foot). That seems to make it impossible to use a 3-unit stress group, characteristic of the structures $3+2+3$ and $3+3+2$ of other runosong regions, at the beginning of a line in Seto songs.

In terms of performance rhythm, a special feature - the method of shortening - is used in refrain songs and laments. Bridal laments use the method to shorten the verse line the most - the $2+2+2+2$ verse structures are always sung to the ...-2-3 performance structure. In refrain songs and death laments it occurs only partly. Additionally, in bridal laments the $2+3+2$ verse structure, based on the ...22 syllable structure, is usually shortened in performance to the ...-2-2 musical structure (the ...-2-2 musical structure is not known in refrain songs and is rarely used in death laments).

The use of both the method of shortening and the $2+3+2$ verse structure results in the centrality of the 5 -unit musical rhythmic pattern, especially in bridal laments. The $3+2$-ending part is also highlighted by the musical harmonic rhythm of the bridal and funeral laments. In the centrality of the 5 -unit rhythmic pattern, the frequent use of the $2+3+2$ verse structure and the method of shortening, which is different from the main body of Seto runosongs with the stable length of lines, the connections to the rituality of refrain songs and laments as well as the special movements performed during bridal laments can be seen. An (additional?) impetus to the use of the method of shortening could also be the historical language change - systematic loss of syllables along with the division of the long syllabic quantity into long (Q2) and overlong (Q3) quantity degree. On the other hand, these peculiarities may be also caused by earlier or later influence from another musical culture.

Most typical metrical structures and performance rhythm structures in different song groups are shown in the following schema (feast - feast song, representing songs of stable length, refrain - group of refrain songs, death 
and bridal - corresponding kinds of laments, verse structures are marked with + and performance rhythm structures with - ; genres where structure is rare are in parentheses; see also Tables 11 and 12). Characteristic coincidence in the alternation of musical harmonic complexes in bridal laments is also indicated.

\begin{tabular}{|c|c|c|c|}
\hline feast, refrain, (death) & $2+3+$ & +3 & \\
\hline feast, refrain, (death) & (2) $-2(1)-3$ & -3 & \\
\hline all & $2+2+$ & $+2+2$ & \\
\hline feast, refrain, death & (2) $-2(1)-2$ - & $2-2$ & \\
\hline frain, death, bridal & (2) $-2(1)-2$ - & 3 & harmonic rhythm XOX|OO \\
\hline frain), death, bridal & $2+3$ & +2 & \\
\hline frain), death, bridal & (2) $-2(1)-3$ & -2 & harmonic rhythm XOX|OO \\
\hline eath), bridal & (2) $-2(1)-2-$ & & \\
\hline
\end{tabular}

The principles of organizing words in the line are based on their quantity degree in the Seto tradition. All the song categories share a similar metric quality of Q1 and Q2 words and a different metric quality of Q3 words. A monosyllabic Q3 word or the initial syllable of a multi-syllabic Q3 word may be stretched over two musical metrical units. The initial syllables of Q1 and Q2 words are not stretched over two musical metrical units, but in turn can be systematically compressed to a single musical metrical unit by using the shortening method. The development of the distinction of the Q1 and Q2 versus $\mathrm{Q} 3$ is linked to the language change in 13.-16. century. The use of quantity degree in specific verse positions is also similar - to make a bold speculation, it may reveal traces of the positioning principles of words according to their quantity, which is characteristic of the Finnic runosong tradition in general (Oras, Sarv 2021).

The Finnic runosong meter is obviously the original or exemplary structural system of Seto runosong meter - and also at least one of the systems forming the lament meter. Belonging to the culturally somewhat isolated border region of Finnic runosong area, it has developed along its own course in the context of a unique musical tradition, changes in language and possible external influences. Metrical regularity of solo and choral laments as well as the existence of choral laments distinguish Seto laments from all other Finnic lament traditions and may link to a possible innovation in Seto tradition. The meter of Seto runosongs shares the most similarities to Southeast-Estonian 
tradition - but there exist also obvious differences. The development of Seto metrics in the context of the neighboring subtraditions of runosong as well as other singing cultures merits further study. ${ }^{30}$

\section{References}

Ambrazevicius Rytis; Pärtlas, Žanna 2011. Searching for the "natural” origins of the symmetrical scales: Traditional multipart Setu songs. In: Journal of Interdisciplinary Music Studies 5(1), 1-17.

Arukask, Madis 2011. Communication Across The Border: What Burial Laments Can Tell Us About Old Beliefs. In: Estonian Journal of Archaeology 15, 2, 130-150. https://doi.org/10.3176/arch.2011.2.04

Asu, Eva Liina; Lippus, Pärtel; Pajusalu, Karl; Teras, Pire 2016. Eesti keele hääldus. Tartu: Tartu Ülikooli Kirjastus.

Boyarkin, Nikolai Ivanovich (ed.) 1988. Pamjatniki Mordovskogo narodnogo muzykal'nogo iskusstva. Vol. 3: Erzjanskie priurochennye pesni i plachi Zavolzh'ja. Saransk: Mordovskoe knizhnoe izdatel'stvo.

Efimenkova, Bronislava Borisovna 1980. Severnorusskaja prichet'. Mezhdureche Sukhony i Juga i verkhov'ja Kokshengi (Vologodskaja oblast'). Moskva: Sovetskij kompozitor.

Frazer, James George 1996 [1922]. The Golden Bough. A Study in Magic and Religion. London: Penguin Books.

Frog 2019. The Finnic Tetrameter - A Creolization of Poetic Form? In: Studia Metrica et Poetica 6(1), 20-78. https://doi.org/10.12697/smp.2019.6.1.02

Frog; Stepanova, Eila 2019. On the Analogical Comparison of Performance Environments: Lament Poetry's Soundscape as a Case Study. In: RMN Newsletter 14, 91-111. https:// www.helsinki.fi/sites/default/files/atoms/files/rmn_14_methodologies.pdf\#page=91

30 This study was supported by the Estonian Ministry of Education and Research (PRG1288 A Corpus-based Approach to Folkloric Variation: Regional Styles, Thematic Networks, and Communicative Modes in Runosong Tradition, EKKD65 - Source Documents in the Cultural Process: Estonian Materials in the Collections and Databases of the Estonian Literary Museum, and EKKD41 - Interdisciplinary corpus of Seto), and by the European Regional Development Fund (Centre of Excellence in Estonian Studies, 2014-2020.4.01.15-0015). The authors cordially thank Frog for his thoughtful comments on the preliminary version of the article. 
Hagu, Paul 2000 [1995]. Poeesia eksam. Setu mõrsjaitkudest kõrvutuses läänemeresoomlaste põhjapoolsema itkutraditsiooniga. In: Salve, Kristi; Kõiva, Mare; Tedre, Ülo (eds.), Tagasipöördumatus. Sõnad ja hääl. Tartu: Eesti Kirjandusmuuseum, 199-227.

Honko, Lauri. 1974. Balto-Finnic Lament Poetry. In: Leino, Pentti; Kaivola-Bregenhøj, Annikki; Vento, Urpo (eds.), Finnish Folkloristics 1. Helsinki: Finnish Literature Society, 9-61.

Jüvä, Sullõv 2002. Võro-eesti synaraamat / Võru-eesti sõnaraamat. Tarto, Võro: Võro Instituut.

Kallio, Kati; Frog; Sarv, Mari 2017. What to Call the Poetic Form: Kalevala-Meter, Regivärss, Runosong, Alliterative Finnic Tetrameter, or Something Else? In: RMN Newsletter 12-13, 139-161.

Kallio, Petri 2014. The Diversification of Proto-Finnic. In: Ahola, Joonas; Frog (eds.), Fibula, Fabula, Fact: The Viking Age in Finland. (Studia Fennica Historica 18.) Helsinki: Suomalaisen Kirjallisuuden Seura, 155-168.

Kallio, Petri 2015. The Stratigraphy of the Germanic Loanwords in Finnic. In: Askedal, John Ole; Nielsen, Hans Frede (eds.), Early Germanic Languages in Contact. (NOWELE Supplement Series 27). Amsterdam, Philadelphia: John Benjamins, 23-38.

Käsi, Inge 2016. Seto sõnastik. Eesti Keele Instituut. http://www.eki.ee/dict/setosonastik/

Kolk, Udo 1979. Problemy setuskogo mnogogolosija. In: Uchenye zapiski Tartuskogo gosudarstvennogo universiteta 501: 90-101.

Konkka, Unelma 1985. Ikuinen ikävä. Karjalaiset riitti-itkut. Helsinki: Suomalaisen Kirjallisuuden Seura.

Krasnopolskaya, Tamara Vsevolodovna 1980. O nekotorykh osobennostjakh muzykal'no-strofovoj formy v karel'skikh prichitanijakh. In: Rüütel, Ingrid (ed.), Finno-ugorskij muzykal'nyj fol'klor i vzaimosvjazi s sosednimi kul'turami. Tallinn: Eesti Raamat, 196-201.

Krasnopolskaya, Tamara Vsevolodovna 1986. O kompozitsionnykh osobennostjakh melostrofy karel'skikh prichitanij. In: Rüütel, Ingrid (ed.), Muzyka v obrjadakh $i$ trudovoj dejatel'nosti finno-ugrov. Tallinn: Eesti Raamat, 216-228.

Küper, Christoph 1988. Sprache und Metrum. Semiotik und Linguistik des Verses. Tübingen: Niemeyer.

Lang, Valter 2018. Läänemeresoome tulemised. Tartu: Tartu Ülikooli Kirjastus. 
Laul, Silvia 1997. Lõunaeestlaste ja volga rahvaste ühiskultuurist. In: Keel ja kirjandus 9, 577-584.

Laul, Silvia 2001. Rauaaja kultuuri kujunemine Eesti kaguosas (500 e.Kr. - 500 p.Kr.). Tallinn: Ajaloo Instituut, Õpetatud Eesti Selts.

Lippus, Pärtel; Pajusalu, Karl 2009. Regional variation in the perception of Estonian quantity. In: Vainio, Martti; Aulanko, Reijo; Aaltonen, Olli (eds.), Nordic Prosody. Proceedings of the Xth Conference, Helsinki 2008. Frankfurt: Peter Lang, 151-157.

Lotman, Mihhail 1998. Värsisüsteemidest. Peamiselt eesti ja vene värsi näitel. In: Akadeemia 9, 1846-1874.

Nenola-Kallio, Aili 1982. Studies in Ingrian Laments. (FF Communication 234). Helsinki: Academia Scientiarum Fennica.

Nenola, Aili 2002. Inkerin itkuvirret. Ingrian laments. Helsinki: Finnish Literature Society.

Niemi, Jarkko 2002. Musical Structures of Ingrian Laments. In: Nenola, Aili (ed.), Inkerin itkuvirret / Ingrian Laments. Helsinki: Finnish Literature Society, 708-728.

Olivetti, Paola 2007. Musical Features of the Ritual Lament in Ancient Greece. In: Rosetta 2, 21-31. http://www.rosetta.bham.ac.uk/Issue_02/Olivetti.pdf

Oras, Janika 1999. Sõprade laulud. Noot ja kommentaar. In: Mäetagused 11, 120-123. http://www.folklore.ee/tagused/nr11/pdf/laul.pdf

Oras, Janika 2004. Helmi Villa regilauluviisid - korrastatud mitmekesisus. In: Sarv, Mari (ed.), Regilaul - loodud või saadud? Tartu: Eesti Kirjandusmuuseum, 89-121.

Oras, Janika 2019. Individual Rhythmic Variation in Oral Poetry: The Runosong Performances of Seto Singers. In: Open Linguistics 5, 569-581.

https://doi.org/10.1515/opli-2019-0031

Oras, Janika, Iva, Sulev 2017. Välted seto regilaulu värsimõõdus. [Quantity degrees in the metre of Seto runosong.] In: Mäetagused 68, 177-194.

https://doi.org/10.7592/MT2017.68.oras_iva

Oras, Janika; Sarv, Mari 2021 (forthcoming). Metrics of Runosongs of the Border Area: Quantity and Broken Lines in Seto Songs. In: Frog, Grünthal, Satu; Kallio, Kati; Niemi, Jarkko (ed.), Versification: Metrics in Practice. (Studia Fennica Litteraria). Helsinki: Finnish Literary Society.

Oras, Janika; Pärtlas, Žanna; Sarv, Mari; Kalkun, Andreas 2021. The Metrics of Seto Choral Laments in the Context of Runosong Metrics: Dataset. https://entu.keeleressursid.ee/public-document/entity-9896 
Pajusalu, Karl 2014. Eesti keele sõnaprosoodia lõuna-läänemeresoome taustal. [Estonian word prosody in the Southern Finnic context.] In: Keel ja Kirjandus $8 / 9,575-589$.

Pärtlas, Žanna 1997. Tähelepanekuid setu laulu laadiehitusest ja mitmehäälsusest. In: Teater. Muusika. Kino 1, 23-28.

Pärtlas, Žanna 2001. Viisi rütmilisest vormist ja laadirütmist setu mitmehäälses rahvalaulus. [The Rhythmic Form and Modal Rhythm of the Melody in the Setu Polyphonic Folk Song.] In: Jaago, Tiiu; Sarv, Mari (ed.), Regilaul - keel, muusika, poeetika. Tartu: Eesti Kirjandusmuuseum. Eesti Rahvaluule Arhiiv; Tartu Ülikool. Eesti ja võrdleva rahvaluule õppetool, 117-152.

Pärtlas, Žanna 2005. K voprosu o skhodstvakh v setuskoj, mordovskoj i juzhnorusskoj pesennykh traditsijakh. [On the Similarities between Seto, Mordovian and SouthRussian Folk Song Traditions.] In: Aun, Mare; Tamla, Ülle (ed.), Setumaa kogumik 3. Uurimusi Setumaa loodusest, ajaloost ja folkloristikast. Tallinn: Tallinna Ülikooli Ajaloo Instituut, 196-237.

Pärtlas, Žanna 2006a. "Sümmeetrilised laadid” ja monointervalliline mitmehäälsus vokaalses rahvamuusikas: mõningaid paralleele setu ja Lõuna-Venemaa rahvalaulu vahel. In: Lintrop, Aado (ed.), Regilaul - esitus ja tõlgendus. Tartu: Eesti Kirjandusmuuseum, 219-248.

Pärtlas, Žanna 2006b. Foundations of the Typology of Setu Folk Tunes. In: Ojamaa, Triinu; Kalkun, Andreas (eds.), Individual and Collective in Traditional Culture. (Töid etnomusikoloogia alalt 4.) Tartu: Eesti Kirjandusmuuseum, 19-28.

Pärtlas, Žanna 2010a. Setu Multipart Singing: Comparison of Written Sources and Sound Recordings. In: Ziegler, Susanne; Bareis, Urban (eds.), Historical Sources and Source Criticism. Stockholm: Svenskt Visarkiv, 227-237.

Pärtlas, Žanna 2010b. A “Hen-and-Egg” Problem: Interrelation Between Scale Structure and Vertical Structure in Setu Multipart Songs. In: Tsurtsumia, Rusudan; Jordania, Joseph (eds.), The Fourth International Symposium on Traditional Polyphony. Proceedings. Tbilisi: International Research Center for Traditional Polyphony of Tbilisi V. Sarajishvili State Conservatory, 336-354. https://drive.google.com/file/d/1-ETpUYUm-ieeh6P7Ujzt7uwk_GV1DfHB/view

Pärtlas, Žanna 2018. The Brides of Death: the Seto Collective Funeral Laments to Maiden. In: Tsurtsumia, Rusudan; Jordania, Joseph (ed.), The Eighth International Symposium on Traditional Polyphony. Tbilisi (Gruusia), 26.-30.09.2016. Proceedings. Tbilisi: International Research Center for Traditional Polyphony of Tbilisi V. Sarajishvili State Conservatory, 220-233. 
Parve, Merike 2003a. Setu välted. In: Lõunaeesti häälikud II. (Tartu Ülikooli eesti keele óppetooli toimetised 27.) Tartu: Tartu Ülikool, 17-48.

Parve, Merike 2003b. Välted lõunaeesti murretes. Dissertationes philologiae estonicae Universitatis Tartuensis 12. Tartu: Tartu Ülikooli Kirjastus.

Pashina, Olga (ed.) 2005. Narodnoe muzykal'noe tvorchestvo. Sankt-Peterburg: Kompozitor.

Pino, Veera; Sarv, Vaike 1981. Setu surnuitkud I. Tallinn: Eesti NSV Teaduste Akadeemia, Keele ja Kirjanduse Instituut.

Rätsep, Huno 1989. Eesti keele tekkimise lugu. In: Akadeemia 7, 1503-1524.

Ross, Jaan; Lehiste, Ilse 2001. The Temporal Structure of Estonian Runic Songs. Berlin, New York: Mouton de Gruyter.

Rüütel, Ingrid 1990. Die Schichten des Volkslieds der Setukesen und ihre etnokulturellen Hintergründe. In: Finnisch-Ugrische Forschungen 49(1/3), 85-128.

Rüütel, Ingrid 1996. Estonian Folk Music Layers in the Context of Ethnic Relations. In: Folklore. An Electronic Journal of Folklore 6.

https://www.folklore.ee/folklore/vol6/ruutel.htm

Rüütel, Ingrid 2010. Lõunavepsa surnuitkuviisid läänemeresoome itku- ja laulutraditsiooni kontekstis. In: Salve, Kristi; Kõiva, Mare; Tedre, Ülo (eds.), Tagasipöördumatus. Sõnad ja hääl. Tartu: Eesti Kirjandusmuuseum, 283-296.

Rüütel, Ingrid; Remmel, Mart 1980. Opyt notatsii i issledovanija vepsskikh prichitanij. In: Rüütel, Ingrid (ed.), Finno-ugorskij muzykal'nyj fol'klor i vzaimosvjazi s sosednimi kul'turami. Tallinn: Eesti Raamat, 169-192.

Salve, Kristi 2000 [1993]. Toone tare. Tähelepanekuid setu surnuitkude žanridevahelistest ja geograafilistest seostest. In: Salve, Kristi; Kõiva, Mare; Tedre, Ülo (eds.), Tagasipöördumatus. Sõnad ja hääl. Tartu: Eesti Kirjandusmuuseum, 55-72.

Sarv, Jaan 1980. Rasshifrovka setuskogo mnogogolosija pri pomoshchi mnogokanal'noj studijnoj apparatury. In: Rüütel, Ingrid (ed.), Finno-ugorskij muzykal'nyj fol'klor $i$ vzaimosvjazi s sosednimi kul'turami. Tallinn: Eesti Raamat, 103-126.

Sarv, Mari 2008. Loomiseks loodud. Regivärsimõõt traditsiooniprotsessis. (Dissertationes folkloristicae Universitatis Tartuensis 11) Tartu: Tartu Ülikooli Kirjastus. http://hdl.handle.net/10062/5358

Sarv, Mari 2011a. Metrical universals in oral poetry. In: Küper, Christoph (ed.), Current Trends in Metrical Analysis. Peter Lang, 329-337. 
Sarv, Mari 2011b. Possible foreign influences on the Estonian regilaul metre: language or culture? In: Lotman, Mihhail; Lotman, Maria-Kristiina (eds.), Frontiers in Comparative Prosody. (Linguistic Insights 113.) Peter Lang, 207-226.

Sarv, Mari 2015. Regional Variation in Folkloric Meter: The Case of Estonian Runosong. In: RMN Newsletter 9, 6-17. http://www.helsinki.fi/folkloristiikka/ English/RMN/RMN_9_Winter_2014-2015.pdf

Sarv, Mari 2019. Poetic metre as a function of language: linguistic grounds for metrical variation in Estonian runosong. In: Studia Metrica et Poetica 6(2), 102-148. https://doi.org/10.12697/smp.2019.6.2.04

Sarv, Vaike 1980. O zakonomernostjakh stroenija zvukorjadov i ritmiki v setuskom muzykal'nom fol'klore (na materiale pesen odnoj zapevaly). In: Rüütel, Ingrid (ed.), Finno-ugorskij muzykal'nyj fol'klor i vzaimosvjazi s sosednimi kul'turami, 129-145.

Sarv, Vaike 1986. Prichitanija nevesty u setu. In: Rüütel, Ingrid (ed.), Muzyka v obrjadakh i trudovoj dejatel'nosti finno-ugrov. Tallinn: Eesti Raamat, 272-284.

Sarv, Vaike 1993. Setu itkuvärsi meetrikast. In: Keel ja Kirjandus 5, 282-292.

Sarv, Vaike 2000a. Setu itk - mõiste ja liigid. In: Salve, Kristi; Kõiva, Mare; Tedre, Ülo (eds.), Tagasipöördumatus. Sõnad ja hääl. Tartu: Eesti Kirjandusmuuseum, 9-37.

Sarv, Vaike 2000b. Setu mõrsjaitku muusikaline struktuur eeslaulja partii põhjal. In: Salve, Kristi; Kõiva, Mare; Tedre, Ülo (eds.), Tagasipöördumatus. Sõnad ja hääl. Tartu: Eesti Kirjandusmuuseum, 123-198.

Sarv, Vaike 2000c. Setu itkukultuur. (Ars musicae popularis 14.) Tartu, Tampere: Eesti Kirjandusmuuseum.

Stepanova, Aleksandra Stepanovna 1985. Metaforicheskij mir karel'skikh prichitanij. Leningrad: Nauka.

Stepanova, Eila 2017. Parallelism in Karelian Laments. In: Oral Tradition 31, 2, 485508. https://doi.org/10.1353/ort.2017.0018

Stepanova, Eila; Frog 2015. Social Movement and a Structural Distribution of Karelian Ritual Genres. In: RMN Newsletter 10, 112-118.

Tampere, Herbert 1934. Eeslaulja ja koor setu rahvalaulude ettekandmisel. In: Eesti Rahva Muuseumi aastaraamat IX/X (1933/34). Tartu: Sihtasutus "Eesti Rahva Muuseum", 49-74.

Tedre, Ülo 2000. Itku relikte eesti pulmakombestikus. In: Salve, Kristi; Kõiva, Mare; Tedre, Ülo (eds.), Tagasipöördumatus. Sõnad ja hääl. Tartu: Eesti Kirjandusmuuseum, 228-237. 
Valk, Heiki 2009. Hilisrauaaeg (1000/1050-1225). In: Valk, Heiki; Selart, Anti; Lillak, Anti (eds.), Setomaa, 2. Vanem ajalugu muinasajast kuni 1920. aastani. Tartu: Eesti Rahva Muuseum, 126-174.

Valk, Heiki 2011. Setomaa asend ajaloolises ruumis: lisamärkusi kaugema mineviku kohta. In: Õpetatud Eesti Seltsi Aastaraamat 2010. Tartu: Õpetatud Eesti Selts, 9-46.

Viitso, Tiit-Rein 2003. Rise and development of the Estonian language. In: Erelt, Mati (ed.), Estonian Language. Linguistica Uralica supplementary series 1. Tallinn: Estonian Academy Publishers, 130-230.

Wilce, James M. 2009. Crying Shame. Metaculture, Modernity, and the Exaggerated Death of Lament. Oxford: Wiley-Blackwell. 